\title{
Influence of Nutrient Solution Temperature on Its Oxygen Level and Growth, Yield and Quality of Hydroponic Cucumber
}

\author{
Muthir S. Al-Rawahy ${ }^{1}$, Salim A. Al-Rawahy ${ }^{2}$, Yaseen A. Al-Mulla ${ }^{2,3} \&$ Saleem K. Nadaf ${ }^{4}$ \\ ${ }^{1}$ Ministry of Agriculture \& Fisheries, Sultanate of Oman \\ ${ }^{2}$ Department of Soils, Water and Agricultural Engineering, College of Agriculture \& Marine Sciences, Sultan \\ Qaboos University, Sultanate of Oman \\ ${ }^{3}$ Remote Sensing and GIS Research Center, Sultan Qaboos University, Sultanate of Oman \\ ${ }^{4}$ Oman Animal \& Plant Genetic Resources Center, The Research Council, Sultanate of Oman \\ Correspondence: Muthir S. Al-Rawahy, Directorate General of Agriculture \& Research, Ministry of Agriculture \\ \& Fisheries, P.O. Box 50 Seeb, PC-121, Sultanate of Oman. Tel: 968-2689-3132. E-mail: marwan07@live.com
}

Received: November 19, 2018

Accepted: December 21, 2018

Online Published: February 15, 2019

doi:10.5539/jas.v11n3p75

URL: https://doi.org/10.5539/jas.v11n3p75

The research is financed by Agriculture \& Fisheries Development Fund (AFDF) of the Ministry of Agriculture \& Fisheries, Sultanate of Oman and part of PhD thesis for submission to the Sultan Qaboos University, Sultanate of Oman.

\begin{abstract}
High nutrient solution temperature stress around root-zone (rhizosphere) is a major factor limiting hydroponic crop growth due to change in dissolved oxygen (DO) levels in nutrient solution during the high-temperature seasons. This suggests that easier and economical control of root-zone temperature (RZT) could be an effective solution to the temperature stress for the crop plants in hydroponics. In this respect, the present investigation was undertaken to comprehend the influence of nutrient solution temperature on its oxygen level (ambient dissolved oxygen in feeding tank), growth, yield and quality of cucumber (Cucumis sativus L.) plants. The plants were cultivated in recirculating hydroponic system in a greenhouse with dimensions of $9 \mathrm{~m}$ wide $\times 30 \mathrm{~m}$ long and total area of $270 \mathrm{~m}^{2}$ during three cropping periods in Oman viz. summer (June-August), fall (September-November) and spring (February-May) in two consecutive years 2016/2017 and 2017/2018. Three cooling treatments were applied viz. T1 $\left(22^{\circ} \mathrm{C}\right)$, T2 $\left(25^{\circ} \mathrm{C}\right)$ and $\mathrm{T} 3\left(28^{\circ} \mathrm{C}\right)$ through cooling nutrient solution besides non-cooled treatment $\mathrm{T} 4\left(33^{\circ} \mathrm{C}\right)$ as control. The plants were grown in pots filled with perlite medium in randomized complete design (RCD) with four replications. All the treatments received the same nutrient concentrations. The results showed that cooling of nutrient solution temperature influenced positively the levels of DO in the fresh nutrient solution feeding tank and drain nutrient solution for all cropping periods in both the years. Significant $(\mathrm{p}<0.05)$ differences between the treatments were observed in oxygen consumption by the roots of cucumber in the cropping periods in both the years. High levels of oxygen consumptions were recorded with cooled RZTs as compared to that of control-non-cooled RZT for all cropping periods in both the years. All growth, production and quality attributes were positively influenced and greatly expressed by cooled root-zone temperature in the root-zone of cucumber with increased DO levels in nutrient solution. This study revealed that availability of optimum aeration (oxygen levels) in nutrient solution through cooling of nutrient solution temperature could be of significance for boosting cucumber yield as observed during all the growing periods especially in summer in Oman.
\end{abstract}

Keywords: root zone, temperature, dissolved oxygen, growth, yield, quality, hydroponics, cucumber

\section{Introduction}

Among the factors affecting hydroponic production systems, the nutrient solution temperature is being considered as one of the most important determining factors of crop yield and quality (Muthir et al., 2018). The temperature of the nutrient solution has a direct relation to the amount of oxygen consumed by plants, and an inverse relation to the oxygen dissolved. Further, the temperature of the nutrient solution is reported to influence the uptake of water and nutrients differentially by the crop (Libia et al., 2012). Many studies have been 
undertaken on the effect of nutrient solution temperatures and their effect on oxygen levels, uptake of nutrients, growth and yield of some vegetable crops grown in hydroponics systems. High solution temperature $\left(35^{\circ} \mathrm{C}\right)$ was found to affect in the short and long-term during growth period of the crop. In the long term, oxygen solubility was found reduced (Falah et al., 2010). Graves (1983) observed that at temperatures below $22{ }^{\circ} \mathrm{C}$ the DO in the nutrient solution is sufficient to cover its demand in tomato plants. Chun and Takakura (1994) reported that the supply of pure, pressurized oxygen gas to the nutrient solution is an oxygen-enriched method which is often used for research as oxy-fertigation. Oxygen deficiency in the root zone could lead to poor root and plant performance and an increase in the incidence of diseases and pests. Further, it is observed that if root zone oxygen dropped below $2.8 \mathrm{mg} / \mathrm{L}$, the tomato plant roots would be much more susceptible to Pythium infection (Che'rif et al., 1997). Root zone oxygen deficiency is of concern during hot summer days in greenhouses for example, Zheng (unpublished data) measured the root zone DO levels in a commercial cucumber greenhouse in Southwest Ontario, Canada in the summer of 2006 and found that the DO dropped to as low as $2 \mathrm{mg} / \mathrm{L}$. In view of the above, the present investigation was carried out to know the effect of root-zone temperature on the dissolved oxygen level in the solution and on root and plant development, growth, yield and quality of cucumber.

\section{Materials and Methods}

\subsection{Study Area}

The experiments were conducted in a cooled greenhouse of dimension $30 \mathrm{~m}$ long $\times 9 \mathrm{~m}$ wide at the Directorate General of Agriculture and Livestock Research in Rumais, Barka around $40 \mathrm{~km}$ north of capital Muscat during three periods of growing cucumber under hydroponics viz. spring temperature period (February-May), summer temperature period (June-August) and fall temperature period (September-November) for two years during 2016/2017 and 2017/2018.

\subsection{Microclimate Monitoring}

Three air temperature and relative humidity sensors (Vaisala HMP60, Campbell scientific, USA) were fixed inside the greenhouse at $10 \mathrm{~m}$ from the cooling pad and at $10 \mathrm{~m}$ from the opposite door side and in the middle of the greenhouse. Inside solar radiation was monitored by pyranometer (CMP3-L14-PT, Campbell scientific, USA) by installing under the cover in the middle of the greenhouse. A data logger (CR1000, Campbell scientific, USA) was used to store all air temperature, relative humidity and solar radiation sensors data.

\subsection{Experiment Layout}

Sixteen growing channels were installed inside the greenhouse. The size of each channel was $5.3 \mathrm{~m}$ long $\times 0.4 \mathrm{~m}$ wide. The growing channels made of cement blocks of size $10 \mathrm{~cm}$ wide and $20 \mathrm{~cm}$ long that represented treatments spaced $1.2 \mathrm{~m}$ apart. The treatments included three root-zone temperatures of cooling nutrient solution viz. RZT1 $\left(22^{\circ} \mathrm{C}\right)$, RZT2 $\left(25^{\circ} \mathrm{C}\right)$ and RZT3 $\left(28^{\circ} \mathrm{C}\right)$ besides the control-uncooled nutrient solution (RZT4) that had root-zone ambient temperature of over $33{ }^{\circ} \mathrm{C}$. The experiment was arranged in Randomized Complete Design (RCD) with four replications. Number of plants in each treatment was $40(20 \times 2)$ with total of 640 plants in the experiment. White plastic mulch (100 micron) was used as insulation between the concrete and polyfoam pots to let drainage water from pots to return smoothly to the feeding tanks. Eight independent feeding tanks (400 liters) equipped with submersible pump (0.5HP Lawara, Italy) were fitted for each treatment. Cooled chiller coils made of cupper $1 / 2$ inch were fixed in each of the six of the eight feeding tanks (the remaining two tanks were for control) equipped with digital temperature sensors (GS3, Decagon Inc., USA) to control and adjust the temperature of the nutrient solution in the feeding tanks. 32 GS3 temperature sensors were arranged in such a manner that two GS3 temperature sensors were inserted in two pots at $15 \mathrm{~cm}$ depth in each treatment with code numbers from 1 to 32 in four replications and connected to the CR1000 data logger which was set at every thirty minutes to record temperature of root zone of the cucumber plants in each treatment. Oxygen meter (Omega, USA) was used to record and measure the dissolved oxygen levels of nutrient solution in feeding tanks of all treatments as well as drain nutrient solution from the each treatment channels.

\subsection{Irrigation and Fertilization}

Eight Intelligent hydroponic dosers consisted of an LCD monitoring screen and three triple pumps (Autogrow system, New Zealand) were installed to monitor conductivity (EC) and $\mathrm{pH}$ of the nutrient solutions automatically by which the plants were fertigated. Seeds of cucumber variety namely; Reema F1 (Trust Seeds ) were seeded in 72 hole trays on 11/5/2016, 29/8/2016, 8/2/2017, 9/5/2017, 17/8/2017 and 12/2/2017 and transplanted in polyfoam pots in greenhouse on 24/5/2016, 8/9/2016, 26/2/2017,22/5/2017, 28/8/2017 and 1/3/2018 soon after third true leaf appeared in first and second year respectively. Drip irrigation lines with emitter 4 liter/hour fixed in each pot was used to irrigate the plants. Time for irrigation was set at one minute for every five-minutes 
starting from 7 am morning up to 6 pm evening during the course of the experiment. Two stock solutions: SS1 containing $3 \mathrm{~kg}$ Calcium nitrate with iron chelate $50 \mathrm{~g}$ diluted in 10 liters of water, SS2 containing $3 \mathrm{~kg}$ NPK (12:12:36+TE) with magnesium sulfate $1.5 \mathrm{~kg}$ diluted in 10 liter of water and SS3 containing 1 liter Nitric acid diluted in $20 \mathrm{~L}$ of water were prepared for each treatment to feed the plants through eight Intelligent hydroponic dosers. At the beginning EC (Electro conductivity) was settled at $2 \mathrm{dSm}^{-1}$ and further increased gradually as the plant growth increased up to $2.5 \mathrm{dSm}^{-1}$ at the end of the crop cycle while $\mathrm{pH}$ was kept at 5.8 to 6.0 from seedling stage terminal of the crop cycle.

\subsection{Observation Recorded}

The observed data that were recorded throughout the experiments were- nutrient solution dissolved oxygen levels in feeding tanks, drain nutrient solution dissolved oxygen levels, oxygen consumption, growth parameters (plant height $(\mathrm{cm})$, leaf number/plant, leaf area index $\left(\mathrm{cm}^{2}\right)$, chlorophyll (SPAD values)), production parameters (fruit number $/ \mathrm{m}^{2}$, yield $(\mathrm{kg} / \mathrm{plot} ; \mathrm{t} / \mathrm{gh})$ ), quality parameters (fruit length $(\mathrm{cm})$, fruit diameter $(\mathrm{cm})$ and total soluble solids (TSS), percentage (\%)) were determined.

\subsection{Statistical Analysis}

Analysis of variance (ANOVA) and multiple comparisons (least significant difference (LSD) were performed using GenStat 12th edition (Payne et al., 2009).

\section{Results}

\subsection{Summer Cropping Period (June-August)}

Summer cropping period in general in Oman and other Arabian Peninsula countries has temperature ranging from $38^{\circ} \mathrm{C}$ to $49{ }^{\circ} \mathrm{C}$ with a relative humidity (RH) varying from-50 to $90 \%$.

\subsubsection{Dissolved Oxygen Levels in Nutrient Solution}

Significant $(\mathrm{p}<0.05)$ differences were observed in dissolved oxygen (DO) levels between nutrient solution temperatures (NST) at different times in both the years 2016/2017 and 2017/2018 for cucumber crop. More DO levels were found at $8 \mathrm{am}(8.3 \mathrm{mg} / \mathrm{L}, 8.5 \mathrm{mg} / \mathrm{L}, 7.3 \mathrm{mg} / \mathrm{L}$ and $7.5 \mathrm{mg} / \mathrm{L})$ morning and $12 \mathrm{pm}(7.9 \mathrm{mg} / \mathrm{L}, 8.0 \mathrm{mg} / \mathrm{L}$, $7.7 \mathrm{mg} / \mathrm{L}$ and $7.2 \mathrm{mg} / \mathrm{L}$ ) in cooled NST-22 ${ }^{\circ} \mathrm{C}$ and cooled NST-25 ${ }^{\circ} \mathrm{C}$ respectively compared to control-uncooled NTS-33 ${ }^{\circ} \mathrm{C}$ with linear $\mathrm{R}^{2}$ of $0.98,0.89,0.96$ and 0.96 in both years 2016/2017 and 2017/2018, respectively (Figures 1a and 1b). High levels of DO were recorded with cooled NST-22 ${ }^{\circ} \mathrm{C}(7.9 \mathrm{mg} / \mathrm{L}$ and $8.1 \mathrm{mg} / \mathrm{L})$, followed by cooled NST-25 ${ }^{\circ} \mathrm{C}(7.3 \mathrm{mg} / \mathrm{L}$ and $7.2 \mathrm{mg} / \mathrm{L})$ with significant $(\mathrm{p}<0.05)$ differences between the control non-cooled NST-33 ${ }^{\circ} \mathrm{C}$, which recorded the lowest DO $(5.1 \mathrm{mg} / \mathrm{L}$ and $5.2 \mathrm{mg} / \mathrm{L})$ with linear $\mathrm{R}^{2}$ of 0.95 and 0.96 in the two years 2016/2017 and 2017/2018, respectively (Figures 2a and 2b).

\subsubsection{Dissolved Oxygen Level in Drain Nutrient Solution}

Significant $(\mathrm{p}<0.05)$ differences were revealed in drain nutrient solution DO levels between RZTs at different times in both the years 2016/2017 and 2017/2018 for cucumber crop. More DO levels were found in drain solution at $8 \mathrm{hrs}(4.4 \mathrm{mg} / \mathrm{L}, 4.5 \mathrm{mg} / \mathrm{L}, 4.3 \mathrm{mg} / \mathrm{L}$ and $4.3 \mathrm{mg} / \mathrm{L}) \mathrm{morning}$ and $12 \mathrm{hrs}(4.4 \mathrm{mg} / \mathrm{L}, 4.4 \mathrm{mg} / \mathrm{L}, 4.2$ $\mathrm{mg} / \mathrm{L}$ and $4.3 \mathrm{mg} / \mathrm{L}$ ) in cooled RZT-22 ${ }^{\circ} \mathrm{C}$ and cooled RZT-25 ${ }^{\circ} \mathrm{C}$, respectively compared to control-non-cooled RZT-33 ${ }^{\circ} \mathrm{C}$ with linear $\mathrm{R}^{2}$ of $0.93,0.94,0.95$ and 0.92 in both the years $2016 / 2017$ and $2017 / 2018$, respectively (Figures $3 \mathrm{a}$ and $3 \mathrm{~b}$ ). Significantly high levels of drain DO were recorded with cooled RZT-22 ${ }^{\circ} \mathrm{C}(4.4 \mathrm{mg} / \mathrm{L}$ and $4.4 \mathrm{mg} / \mathrm{L})$, followed by cooled RZT- $25{ }^{\circ} \mathrm{C}(4.2 \mathrm{mg} / \mathrm{L}$ and $4.2 \mathrm{mg} / \mathrm{L})$ compared to the control-uncooled RZT-33 ${ }^{\circ} \mathrm{C}$, which recorded the lowest drain DO $(2.6 \mathrm{mg} / \mathrm{L}$ and $2.6 \mathrm{mg} / \mathrm{L})$ with linear $\mathrm{R}^{2}$ of 0.94 and 0.94 in the two years 2016/2017 and 2017/2018, respectively (Figures 4a and 4b). 


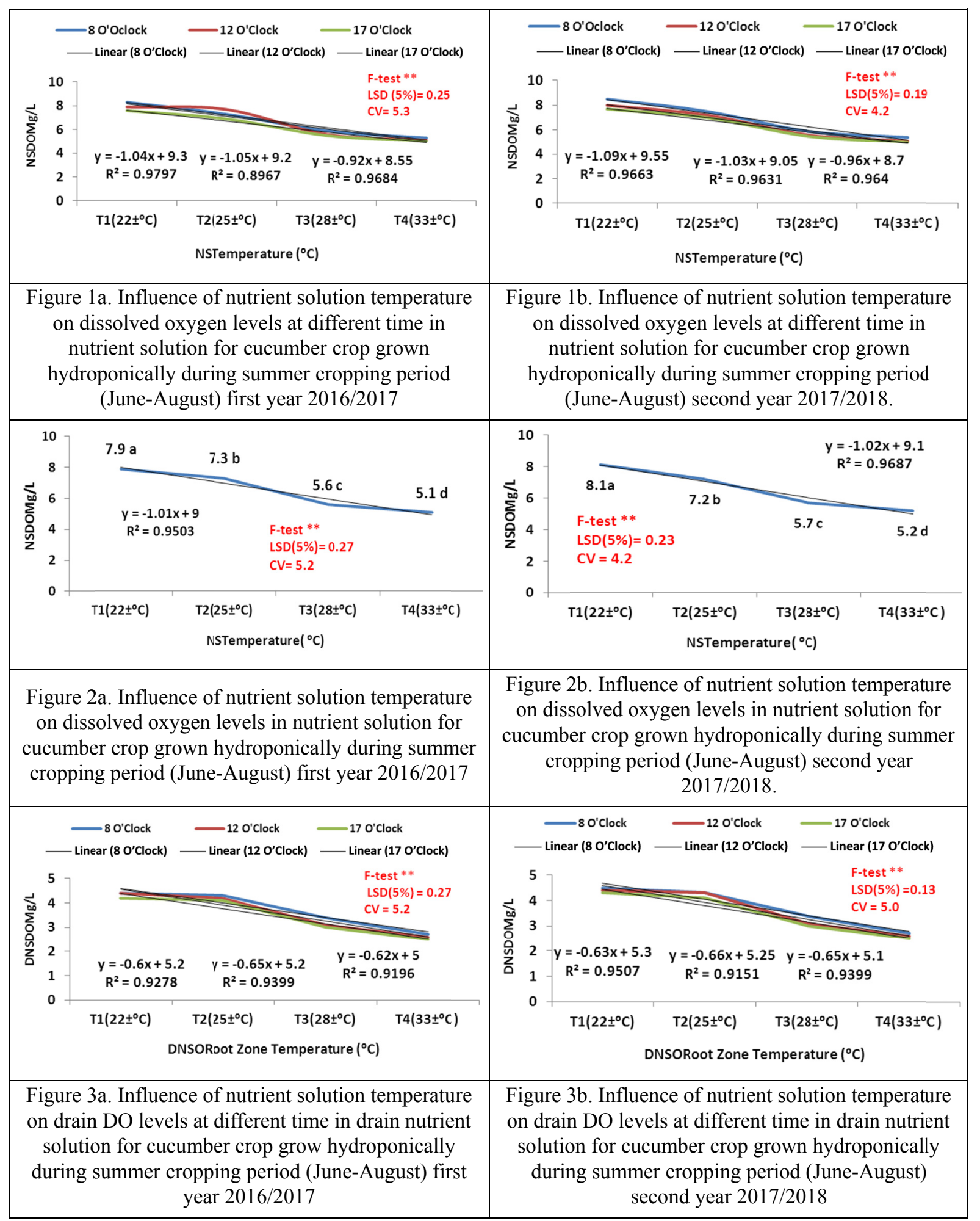




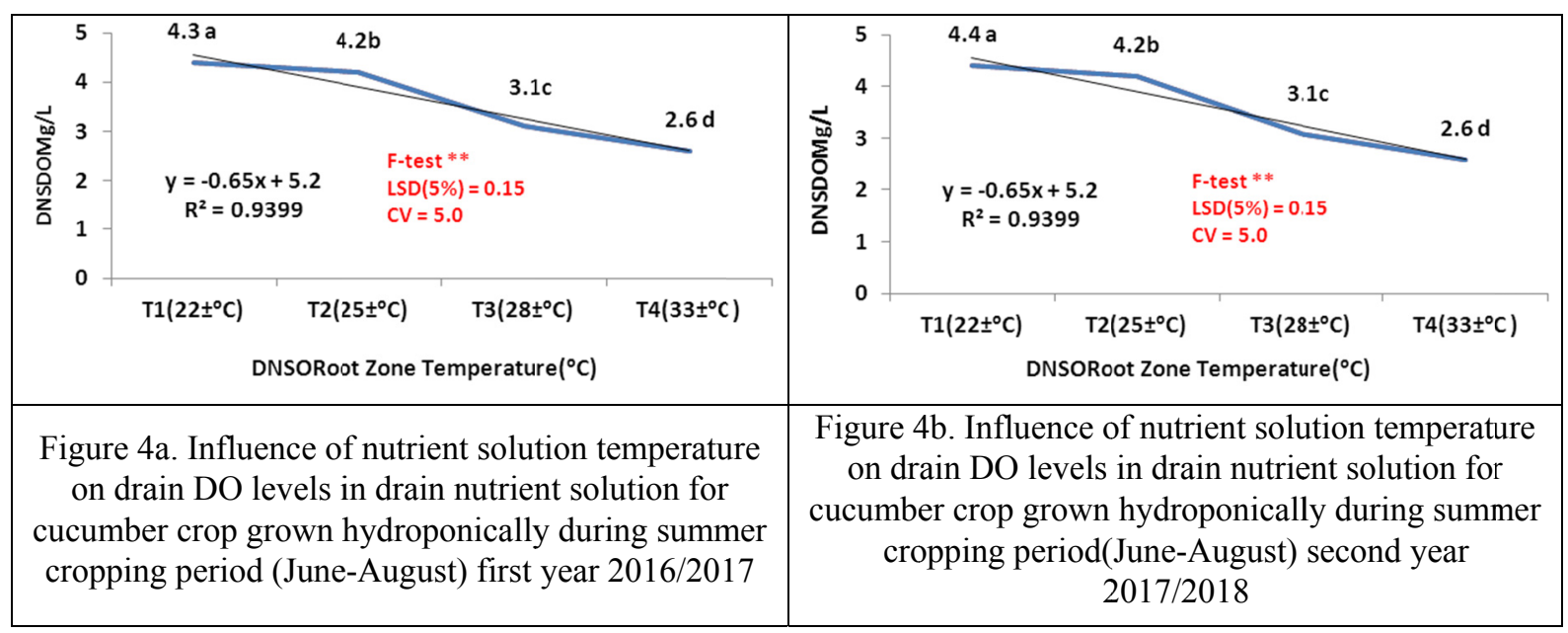

\subsubsection{Dissolved Oxygen Consumption}

Significant $(\mathrm{p}<0.05)$ differences were observed in DO consumption by roots between the treatments in both the years 2016/2017 and 2017/2018. DO consumption by the roots of cucumber ranged from $2.5 \mathrm{mg} / \mathrm{L}$ to $3.6 \mathrm{mg} / \mathrm{L}$ in the first year and from $2.5 \mathrm{mg} / \mathrm{L}$ to $3.7 \mathrm{mg} / \mathrm{L}$ in the second year. High DO consumption by the roots was recorded at cooled RZT- $22{ }^{\circ} \mathrm{C}(3.6 \mathrm{mg} / \mathrm{L}$ and $3.7 \mathrm{mg} / \mathrm{L})$, followed by that at cooled RZT- $25{ }^{\circ} \mathrm{C}(3.1 \mathrm{mg} / \mathrm{L}$ and 3.0 $\mathrm{mg} / \mathrm{L})$. The lowest DO consumption was given by control-uncooled RZT- $33{ }^{\circ} \mathrm{C}(2.5 \mathrm{mg} / \mathrm{L}$ and $2.5 \mathrm{mg} / \mathrm{L})$ in both the years (Table 1).

Table 1. Dissolved Oxygen (DO) input, output and consumption at four RZTs in cucumber grown in hydroponic closed system during summer cropping period (June-August) in cooled greenhouse

\begin{tabular}{|c|c|c|c|c|c|c|}
\hline \multirow[b]{2}{*}{ RZT } & \multicolumn{3}{|c|}{ First year 2016/2017 } & \multicolumn{3}{|c|}{ Second year 2017/2018 } \\
\hline & $\begin{array}{l}\text { DO mg/L } \\
\text { input }\end{array}$ & $\begin{array}{l}\text { DO mg/L } \\
\text { output }\end{array}$ & $\begin{array}{l}\text { DO mg/L } \\
\text { consumption }\end{array}$ & $\begin{array}{l}\text { DO mg/L } \\
\text { input }\end{array}$ & $\begin{array}{l}\text { DO mg/L } \\
\text { output }\end{array}$ & $\begin{array}{l}\text { DO mg/L } \\
\text { consumption }\end{array}$ \\
\hline $22{ }^{\circ} \mathrm{C}$ & $7.9 \mathrm{a}$ & $4.3 \mathrm{a}$ & $3.6 \mathrm{a}$ & $8.1 \mathrm{a}$ & $4.4 \mathrm{a}$ & $3.7 \mathrm{a}$ \\
\hline $25^{\circ} \mathrm{C}$ & $7.3 \mathrm{~b}$ & $4.2 \mathrm{a}$ & $3.1 \mathrm{~b}$ & $7.2 \mathrm{~b}$ & $4.2 \mathrm{a}$ & $3.0 \mathrm{~b}$ \\
\hline $28^{\circ} \mathrm{C}$ & $5.6 \mathrm{c}$ & $3.1 \mathrm{~b}$ & $2.5 \mathrm{c}$ & $5.7 \mathrm{c}$ & $3.1 \mathrm{~b}$ & $2.6 \mathrm{c}$ \\
\hline $33^{\circ} \mathrm{C}$ & $5.1 \mathrm{~d}$ & $2.6 \mathrm{c}$ & $2.5 \mathrm{c}$ & $5.2 \mathrm{~d}$ & $2.6 \mathrm{c}$ & $2.5 \mathrm{c}$ \\
\hline \multicolumn{7}{|c|}{ Statistical Parameters } \\
\hline F-test & $* *$ & $* *$ & $* *$ & $* *$ & $* *$ & $* *$ \\
\hline $\operatorname{LSD}(5 \%)$ & 0.29 & 0.13 & 0.35 & 0.23 & 0.15 & 0.29 \\
\hline $\mathrm{CV} \%$ & 5.3 & 5.2 & 14.3 & 4.2 & 5.0 & 11.8 \\
\hline
\end{tabular}

\subsubsection{Growth Parameters}

Just like cooled root-zone temperature DO levels in the root-zones of cucumber were positively influenced by increased DO levels in nutrient solution and root-zones of the plants, growth parameters such as plant height, leaf number, leaf area and chlorophyll content of cucumber were also found positively influenced as evidenced by significant $(\mathrm{p}<0.05)$ differences between the cooled RZTs and control-uncooled RZT- $33^{\circ} \mathrm{C}$ in both the years. High plant heights were produced by the plants at cooled RZT- $22{ }^{\circ} \mathrm{C}(173.4 \mathrm{~cm}$ and $157.4 \mathrm{~cm})$, followed by those at cooled RZT- $25{ }^{\circ} \mathrm{C}(155 \mathrm{~cm}$ and $157.5 \mathrm{~cm})$ with high DO levels $(7.9 \mathrm{mg} / \mathrm{L}$ and $8.2 \mathrm{mg} / \mathrm{L})$ and $(7.3 \mathrm{mg} / \mathrm{L}$ and $7.2 \mathrm{mg} / \mathrm{L})$, whereas the lowest plant height was given by control-non-cooled RZT-33 ${ }^{\circ} \mathrm{C}(141 \mathrm{~cm}$ and $132 \mathrm{~cm})$ with low DO levels $(5.1 \mathrm{mg} / \mathrm{L}$ and $5.2 \mathrm{mg} / \mathrm{L}$ ) respectively, in both the years (Table 2). There was similar trend in response of cucumber plants with respect to leaf number, leaf area and chlorophyll content at cooled RZT- $22{ }^{\circ} \mathrm{C}$ and cooled RZT- $25^{\circ} \mathrm{C}$ that produced high leaf number, leaf area and chlorophyll content with high DO levels in both years (Table 2). 
Table 2. DO and growth parameters as affected by RZT of cucumber grown in hydroponic system during summer cropping period (June-August) in cooled greenhouse

\begin{tabular}{|c|c|c|c|c|c|c|c|c|c|c|}
\hline \multirow[b]{2}{*}{ RZT } & \multicolumn{5}{|c|}{ First Year 2016/2017 } & \multicolumn{5}{|c|}{ Second Year 2017/2018 } \\
\hline & $\begin{array}{l}\mathrm{DO} \\
\mathrm{mg} / \mathrm{L}\end{array}$ & $\begin{array}{l}\text { Plant } \\
\text { height } \mathrm{cm}\end{array}$ & $\begin{array}{l}\text { Leaf } \\
\text { number/plant }\end{array}$ & $\begin{array}{l}\text { Leaf } \\
\text { area } \mathrm{cm}^{2}\end{array}$ & $\begin{array}{l}\text { Chlorophyll } \\
\text { SPAD }\end{array}$ & $\begin{array}{l}\mathrm{DO} \\
\mathrm{mg} / \mathrm{L}\end{array}$ & $\begin{array}{l}\text { Plant } \\
\text { height } \mathrm{cm}\end{array}$ & $\begin{array}{l}\text { Leaf } \\
\text { number/plant }\end{array}$ & $\begin{array}{l}\text { Leaf } \\
\text { area } \mathrm{cm}^{2}\end{array}$ & $\begin{array}{l}\text { Chlorophyll } \\
\text { SPAD }\end{array}$ \\
\hline $22^{\circ} \mathrm{C}$ & $7.9 \mathrm{a}$ & $173.4 \mathrm{a}$ & $30 \mathrm{a}$ & $346.9 \mathrm{a}$ & $45.3 \mathrm{~b}$ & $8.1 \mathrm{a}$ & $157.4 \mathrm{a}$ & $34 \mathrm{a}$ & $356.6 \mathrm{a}$ & $49.1 \mathrm{a}$ \\
\hline $25^{\circ} \mathrm{C}$ & $7.3 \mathrm{~b}$ & $155.0 \mathrm{~b}$ & $28 \mathrm{a}$ & $345.9 \mathrm{~b}$ & $48.0 \mathrm{a}$ & $7.2 \mathrm{~b}$ & $157.5 \mathrm{a}$ & $34 \mathrm{a}$ & $347.8 \mathrm{a}$ & $47.4 \mathrm{~b}$ \\
\hline $28^{\circ} \mathrm{C}$ & $5.6 \mathrm{c}$ & $170.3 \mathrm{a}$ & $29 \mathrm{a}$ & $292 \mathrm{c}$ & $43.0 \mathrm{c}$ & $5.7 \mathrm{c}$ & $127 \mathrm{~b}$ & $29 \mathrm{~b}$ & $285.0 \mathrm{~b}$ & $44.9 \mathrm{c}$ \\
\hline $33^{\circ} \mathrm{C}$ & $5.1 \mathrm{~d}$ & $141.0 \mathrm{c}$ & $27 \mathrm{~b}$ & $205 \mathrm{~d}$ & $44.3 \mathrm{bc}$ & $5.2 \mathrm{~d}$ & $132 \mathrm{~b}$ & $30 \mathrm{~b}$ & $207.0 \mathrm{c}$ & $43.1 \mathrm{~d}$ \\
\hline \multicolumn{11}{|c|}{ Statistical Parameters } \\
\hline F-test & $* *$ & $* *$ & $* *$ & $* *$ & $* *$ & $* *$ & $* *$ & $* *$ & $* *$ & $* *$ \\
\hline $\operatorname{LSD}(5 \%)$ & 0.27 & 12.2 & 1.3 & 57.2 & 1.5 & 0.23 & 10.9 & 1.1 & 54.1 & 1.4 \\
\hline $\mathrm{CV} \%$ & 5.2 & 17.2 & 10.6 & 12.5 & 7.2 & 4.2 & 6.9 & 8.1 & 11.7 & 6.9 \\
\hline
\end{tabular}

\subsubsection{Yield Parameters}

Cooled nutrient solution temperature were found influencing DO levels in the root-zone of cucumber by increased DO levels in nutrient solution and root-zone of the plants which further influenced greatly the yield parameters considered for study like fruit number $/ \mathrm{m}^{2}$ and yield $\left(\mathrm{kg} / \mathrm{m}^{2}\right)$. Significant $(\mathrm{p}<0.05)$ effects were observed between cooled RZTs and control-non-cooled RZT- $33{ }^{\circ} \mathrm{C}$ in DO levels, fruit number and yield $\left(\mathrm{kg} / \mathrm{m}^{2}\right)$ in both the years. High fruit number $/ \mathrm{m}^{2}$ were produced by cooled RZT- $22{ }^{\circ} \mathrm{C}\left(180 / \mathrm{m}^{2}\right.$ and $\left.220 / \mathrm{m}^{2}\right)$ and cooled RZT- $25{ }^{\circ} \mathrm{C}\left(167 / \mathrm{m}^{2}\right.$ and $\left.221 / \mathrm{m}^{2}\right)$ with high DO levels $(7.9 \mathrm{mg} / \mathrm{L}$ and $8.1 \mathrm{mg} / \mathrm{L})$ and $(7.3 \mathrm{mg} / \mathrm{L}$ and $7.2 \mathrm{mg} / \mathrm{L})$, while the lowest was given by the control $\left(101 / \mathrm{m}^{2}\right.$ and $\left.133 / \mathrm{m}^{2}\right)$ with low DO levels $(5.1 \mathrm{mg} / \mathrm{L}$ and $5.2 \mathrm{mg} / \mathrm{L})$ in both the years (Table 3). High yield was obtained with cooled RZT- $22{ }^{\circ} \mathrm{C}$ to the extent of $18.4 \mathrm{~kg} / \mathrm{m}^{2}, 22.4 \mathrm{~kg} / \mathrm{m}^{2}$ equivalent to $5.0 \mathrm{t} / \mathrm{gh}$ and $6.1 \mathrm{t} / \mathrm{gh}$ with high DO levels $(7.9 \mathrm{mg} / \mathrm{L}$ and $8.1 \mathrm{mg} / \mathrm{L})$, followed by cooled RZT- $25^{\circ} \mathrm{C}$ $\left(16.4 \mathrm{~kg} / \mathrm{m}^{2}\right.$ and $22.1 \mathrm{~kg} / \mathrm{m}^{2}$ equivalent to $4.4 \mathrm{t} / \mathrm{gh}$ and $\left.6.0 \mathrm{t} / \mathrm{gh}\right)$ with high DO levels $(7.3 \mathrm{mg} / \mathrm{L}$ and $7.2 \mathrm{mg} / \mathrm{L})$. The lowest yield was produced by control-non-cooled RZT- $33{ }^{\circ} \mathrm{C}\left(10.4 \mathrm{~kg} / \mathrm{m}^{2}\right.$ and $13.1 \mathrm{~kg} / \mathrm{m}^{2}$ equivalent to 2.8 $\mathrm{t} / \mathrm{gh}$ and $3.5 / \mathrm{gh})$ with low DO levels $(5.1 \mathrm{mg} / \mathrm{L}$ and $5.2 \mathrm{mg} / \mathrm{L})$ in both the years (Table 3).

Table 3. DO and yield parameters as affected by RZT of cucumber grown in hydroponic system during summer cropping period (June-August) in cooled greenhouse

\begin{tabular}{|c|c|c|c|c|c|c|}
\hline \multirow{2}{*}{ RZT } & \multicolumn{3}{|c|}{ First year 2016/2017 } & \multicolumn{3}{|c|}{ Second year 2017/2018 } \\
\hline & $\mathrm{DO} \mathrm{mg} / \mathrm{L}$ & Fruit. $\mathrm{No} / \mathrm{m}^{2}$ & Yield $\mathrm{t} / \mathrm{gh}$ & $\mathrm{DO} \mathrm{mg} / \mathrm{L}$ & Fruit. No/m2 & Yield t/gh \\
\hline $22^{\circ} \mathrm{C}$ & $7.9 \mathrm{a}$ & $180 \mathrm{a}$ & $5.0 \mathrm{a}$ & $8.1 \mathrm{a}$ & $220 \mathrm{a}$ & $6.1 \mathrm{a}$ \\
\hline $25^{\circ} \mathrm{C}$ & $7.3 \mathrm{~b}$ & $167 \mathrm{a}$ & $4.4 \mathrm{a}$ & $7.2 \mathrm{~b}$ & $221 \mathrm{a}$ & $6.0 \mathrm{a}$ \\
\hline $28^{\circ} \mathrm{C}$ & $5.6 \mathrm{c}$ & $178 \mathrm{a}$ & $4.7 \mathrm{a}$ & $5.7 \mathrm{c}$ & $143 \mathrm{~b}$ & $3.8 \mathrm{~b}$ \\
\hline $33^{\circ} \mathrm{C}$ & $5.1 \mathrm{~d}$ & $101 \mathrm{~b}$ & $2.8 \mathrm{~b}$ & $5.2 \mathrm{~d}$ & $133 \mathrm{~b}$ & $3.5 \mathrm{~b}$ \\
\hline \multicolumn{7}{|c|}{ Statistical Parameters } \\
\hline F-test & $* *$ & $* *$ & $* *$ & $* *$ & $* *$ & $* *$ \\
\hline $\operatorname{LSD}(5 \%)$ & 0.27 & 44.5 & 1.2 & 0.23 & 53 & 1.5 \\
\hline $\mathrm{CV} \%$ & 5.2 & 18.5 & 18.5 & 4.2 & 19.1 & 20.3 \\
\hline
\end{tabular}

\subsubsection{Quality Attributes}

Cooled nutrient solution temperature was found to increase DO levels in nutrient solution and root-zone of cucumber plants. However, increased DO levels did not affect fruit length and fruit diameters whereas total soluble solids percentage as brix was increased significantly at cooled RZT in both the years 2016/2017 and $2017 / 2018$ (Table 4). High total soluble solids were given by cooled RZT- $25{ }^{\circ} \mathrm{C}(2.9 \%$ and $2.9 \%)$ with DO levels of $(7.3 \mathrm{mg} / \mathrm{L}$ and $7.2 \mathrm{mg} / \mathrm{L})$ and cooled RZT- $28^{\circ} \mathrm{C}(2.6 \%$ and $2.6 \%)$ with DO levels of $(5.6 \mathrm{mg} / \mathrm{L}$ and $5.7 \mathrm{mg} / \mathrm{L})$, respectively (Table 5). The lowest total soluble solids as brix was given by control-non-cooled RZT-33 ${ }^{\circ} \mathrm{C}(2.4 \%$ and $2.4 \%$ ) with DO levels $(5.1 \mathrm{mg} / \mathrm{L}$ and $5.2 \mathrm{mg} / \mathrm{L})$. However, differences in fruit length, fruit diameter and total soluble solids between the cooled RZTs and non-cooled RZT DO levels were not significant $(p>0.045)$ (Table 4). 
Table 4. DO and growth quality attributes as affected by RZT of cucumber grown in hydroponic closed system during summer cropping period (June-August) in cooled greenhouse

\begin{tabular}{|c|c|c|c|c|c|c|c|c|}
\hline \multirow[b]{2}{*}{ RZT } & \multicolumn{4}{|c|}{ First year 2016/2017 } & \multicolumn{4}{|c|}{ Second year 2017/2018 } \\
\hline & $\begin{array}{l}\mathrm{DO} \\
\mathrm{mg} / \mathrm{L}\end{array}$ & $\begin{array}{l}\text { Fruit } \\
\text { length cm }\end{array}$ & $\begin{array}{l}\text { Fruit } \\
\text { diameter } \mathrm{cm}\end{array}$ & $\begin{array}{l}\text { Total soluble } \\
\text { solids (\%) }\end{array}$ & $\begin{array}{l}\mathrm{DO} \\
\mathrm{mg} / \mathrm{L}\end{array}$ & $\begin{array}{l}\text { Fruit } \\
\text { length } \mathrm{cm}\end{array}$ & $\begin{array}{l}\text { Fruit } \\
\text { diameter } \mathrm{cm}\end{array}$ & $\begin{array}{l}\text { Total soluble } \\
\text { solids }(\%)\end{array}$ \\
\hline $22^{\circ} \mathrm{C}$ & $7.9 \mathrm{a}$ & 15.5 & 3.2 & $2.5 \mathrm{~b}$ & $8.1 \mathrm{a}$ & 15.5 & 3.2 & $2.5 \mathrm{~b}$ \\
\hline $25^{\circ} \mathrm{C}$ & $7.3 \mathrm{~b}$ & 15.2 & 3.1 & $2.9 \mathrm{a}$ & $7.2 \mathrm{~b}$ & 15.3 & 3.1 & $2.9 \mathrm{a}$ \\
\hline $28^{\circ} \mathrm{C}$ & $5.6 \mathrm{c}$ & 15.3 & 3.1 & $2.6 \mathrm{ab}$ & $5.7 \mathrm{c}$ & 15.2 & 3.1 & $2.6 \mathrm{ab}$ \\
\hline $33^{\circ} \mathrm{C}$ & $5.1 \mathrm{~d}$ & 16.1 & 3.0 & $2.4 \mathrm{~b}$ & $5.2 \mathrm{~d}$ & 16.0 & 3.0 & $2.4 \mathrm{~b}$ \\
\hline \multicolumn{9}{|c|}{ Statistical Parameters } \\
\hline F-test & $* *$ & NS & NS & $* *$ & $* *$ & NS & NS & $* *$ \\
\hline $\operatorname{LSD}(5 \%)$ & 0.27 & 0.94 & 0.24 & 0.4 & 0.23 & 0.95 & 0.24 & 0.95 \\
\hline $\mathrm{CV} \%$ & 5.2 & 3.9 & 5.4 & 10.2 & 4.2 & 4.0 & 4.9 & 4.0 \\
\hline
\end{tabular}

\subsection{Fall Cropping Period (September-November)}

Fall cropping period in general in Oman and other Arabian Peninsula countries has temperature ranging from 30 ${ }^{\circ} \mathrm{C}$ to $40{ }^{\circ} \mathrm{C}$ with a relative humidity (RH) varying from 50 to $85 \%$.

\subsubsection{Nutrient Solution Dissolved Oxygen Levels}

Significant $(\mathrm{p}<0.05)$ differences were recorded in DO levels between nutrient NSTs at different times of recording in both the years 2016/2017 and 2017/2018 in cucumber. High DO levels were recoded at 8 am (8.3 $\mathrm{mg} / \mathrm{L}, 8.7 \mathrm{mg} / \mathrm{L}$ and $7.3 \mathrm{mg} / \mathrm{L}$ and $7.5 \mathrm{mg} / \mathrm{L})$ morning and at $12 \mathrm{pm}(8.2 \mathrm{mg} / \mathrm{L}, 8.0 \mathrm{mg} / \mathrm{L}, 6.8 \mathrm{mg} / \mathrm{L}$ and $7.1 \mathrm{mg} / \mathrm{L})$ at cooled NST- $22{ }^{\circ} \mathrm{C}$ and cooled NST- $25{ }^{\circ} \mathrm{C}$, respectively while the lowest was recoded by control-uncooled NST-33C with linear $\mathrm{R}^{2}$ of $0.93,0.93,0.95$ and 0.94 in both the years $2016 / 2017$ and 2017/2018, respectively (Figures $5 \mathrm{a}$ and $5 \mathrm{~b}$ ). Highest levels of DO were found at cooled NST-22 ${ }^{\circ} \mathrm{C}(8.0 \mathrm{mg} / \mathrm{L}$ and $8.2 \mathrm{mg} / \mathrm{L})$, followed by cooled NST-25 ${ }^{\circ} \mathrm{C}(7.0 \mathrm{mg} / \mathrm{L}$ and $7.2 \mathrm{mg} / \mathrm{L})$ with significant $(\mathrm{p}<0.05)$ differences between control-non-cooled NST- $33{ }^{\circ} \mathrm{C}$ which recorded the lowest DO $(5.2 \mathrm{mg} / \mathrm{L}$ and $5.0 \mathrm{mg} / \mathrm{L})$ with linear $\mathrm{R}^{2}$ of 0.93 and 0.96 in two years, 2016/2017 and 2017/2018, respectively (Figures 6a and 6b).

\subsubsection{Dissolved Oxygen Level in Drain Nutrient Solution}

Significant $(\mathrm{p}<0.05)$ differences were observed in DO levels in drain nutrient solution between RZT at different timings of recording in both the years in cucumber. More DO levels were found at $8 \mathrm{am}(3.6 \mathrm{mg} / \mathrm{L}, 3.6 \mathrm{mg} / \mathrm{L}, 3.4$ $\mathrm{mg} / \mathrm{L}$ and $3.4 \mathrm{mg} / \mathrm{L})$ morning and $12 \mathrm{pm}(3.6 \mathrm{mg} / \mathrm{L}, 3.6 \mathrm{mg} / \mathrm{L}, 3.4 \mathrm{mg} / \mathrm{L}$ and $3.4 \mathrm{mg} / \mathrm{L})$ in cooled RZT-22 ${ }^{\circ} \mathrm{C}$ and cooled RZT- $25{ }^{\circ} \mathrm{C}$, respectively compared to control-non-cooled RZT- $33{ }^{\circ} \mathrm{C}$ with linear $\mathrm{R}^{2}$ of $0.82,0.81,0.85$ and 0.85 in both the years (Figures 7a and 7b). High levels of DO levels were recorded with cooled RZT- $22{ }^{\circ} \mathrm{C}$ $(3.5 \mathrm{mg} / \mathrm{L}$ and $3.6 \mathrm{mg} / \mathrm{L})$, followed by cooled RZT- $25^{\circ} \mathrm{C}(3.4 \mathrm{mg} / \mathrm{L}$ and $3.5 \mathrm{mg} / \mathrm{L})$ with significant $(\mathrm{p}<0.05)$ effect between control-uncooled RZT- $33{ }^{\circ} \mathrm{C}$ which gave lowest DO levels $(2.2 \mathrm{mg} / \mathrm{L}$ and $2.2 \mathrm{mg} / \mathrm{L})$ with linear $\mathrm{R}^{2}$ of 0.83 and 0.81 in the two years $2016 / 2017$ and 2017/2018, respectively (Figures $8 \mathrm{a}$ and 8 b). 


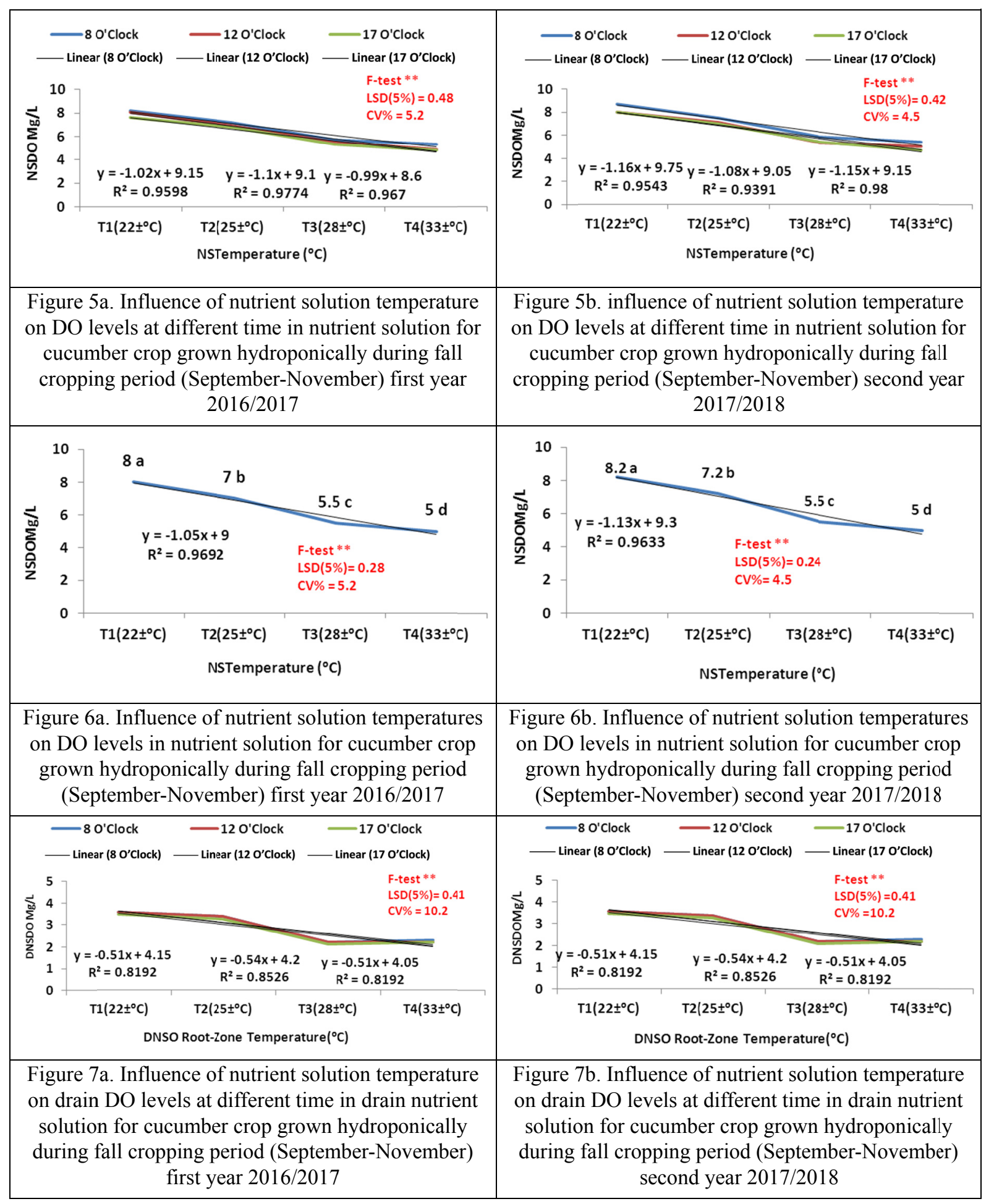




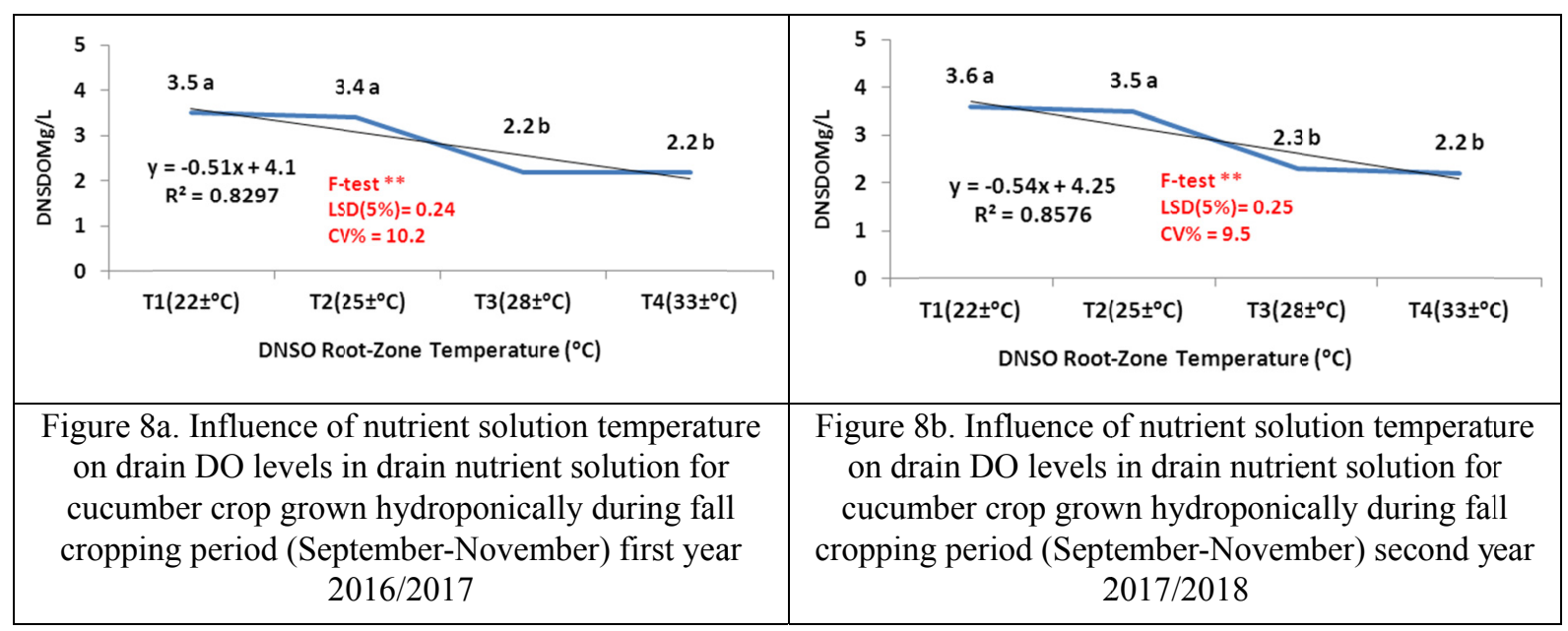

\subsubsection{Dissolved Oxygen Consumption}

Significant $(\mathrm{p}<0.05)$ differences were revealed in DO consumption by the root of the plants at different root-zone temperatures in both the years 2016/2017 and 2017/2018 (Figures 10a and 10b). Oxygen consumption by the roots of cucumber varied from $2.8 \mathrm{mg} / \mathrm{L}$ to $4.5 \mathrm{mg} / \mathrm{L}$ in first the year $2016 / 2017$ and from $2.8 \mathrm{mg} / \mathrm{L}$ to 4.6 $\mathrm{mg} / \mathrm{L}$ in second the year $2017 / 2018$ at different root zone temperatures. Higher oxygen consumption by the roots were recorded at cooled RZT- $22{ }^{\circ} \mathrm{C}(4.5 \mathrm{mg} / \mathrm{L}$ and $4.6 \mathrm{mg} / \mathrm{L})$, followed by those at cooled RZT- $25{ }^{\circ} \mathrm{C}(3.6 \mathrm{mg} / \mathrm{L}$ and $3.7 \mathrm{mg} / \mathrm{L})$, while the lowest was given by control-non-cooled RZT-33 ${ }^{\circ} \mathrm{C}(2.8 \mathrm{mg} / \mathrm{L}$ and $2.8 \mathrm{mg} / \mathrm{L})$ in both the years 2016/2017 and 2017/2018 (Table 5).

Table 5. Oxygen $\left(\mathrm{O}_{2}\right)$ input, output and consumption of cucumber crop at four RZT grown in hydroponic closed system during fall cropping period (September-November) in cooled greenhouse

\begin{tabular}{|c|c|c|c|c|c|c|}
\hline \multirow[b]{2}{*}{ RZT } & \multicolumn{3}{|c|}{ First year 2016/2017 } & \multicolumn{3}{|c|}{ Second year 2017/2018 } \\
\hline & $\begin{array}{l}\text { DO mg/L } \\
\text { input }\end{array}$ & $\begin{array}{l}\text { DO mg/L } \\
\text { output }\end{array}$ & $\begin{array}{l}\mathrm{DO} \mathrm{mg} / \mathrm{L} \\
\text { consumption }\end{array}$ & $\begin{array}{l}\text { DO mg/L } \\
\text { input }\end{array}$ & $\begin{array}{l}\text { DO mg/L } \\
\text { output }\end{array}$ & $\begin{array}{l}\mathrm{DO} \mathrm{mg} / \mathrm{L} \\
\text { consumption }\end{array}$ \\
\hline $22{ }^{\circ} \mathrm{C}$ & $8.0 \mathrm{a}$ & $3.5 \mathrm{a}$ & $4.5 \mathrm{a}$ & $8.2 \mathrm{a}$ & $3.6 \mathrm{a}$ & $4.6 \mathrm{a}$ \\
\hline $25^{\circ} \mathrm{C}$ & $7.0 \mathrm{~b}$ & $3.4 \mathrm{a}$ & $3.6 \mathrm{~b}$ & $7.2 \mathrm{~b}$ & $3.5 \mathrm{a}$ & $3.7 \mathrm{~b}$ \\
\hline $28^{\circ} \mathrm{C}$ & $5.5 \mathrm{c}$ & $2.2 \mathrm{~b}$ & $3.3 \mathrm{c}$ & $5.5 \mathrm{c}$ & $2.3 \mathrm{~b}$ & $3.2 \mathrm{c}$ \\
\hline $33^{\circ} \mathrm{C}$ & $5.0 \mathrm{~d}$ & $2.2 \mathrm{~b}$ & $2.8 \mathrm{~d}$ & $5.0 \mathrm{~d}$ & $2.2 \mathrm{c}$ & $2.8 \mathrm{~d}$ \\
\hline \multicolumn{7}{|c|}{ Statistical Parameters } \\
\hline F-test & $* *$ & $* *$ & $* *$ & $* *$ & $* *$ & $* *$ \\
\hline $\operatorname{LSD}(5 \%)$ & 0.28 & 0.24 & 0.48 & 0.24 & 0.24 & 0.28 \\
\hline $\mathrm{CV} \%$ & 5.2 & 10.2 & 9.5 & 4.5 & 10.2 & 9.2 \\
\hline
\end{tabular}

\subsubsection{Growth Parameters}

Increased DO levels in nutrient solution in the plants at low root zone temperatures had a positive effect of the expression of the growth parameters such as plant height, leaf number, leaf area and chlorophyll content of cucumber. The results were significantly $(\mathrm{p}<0.05)$ different between the cooled RZTs and control-RZT- $33{ }^{\circ} \mathrm{C}$ in plant height $\mathrm{cm}$, leaf number, leaf area $\left(\mathrm{cm}^{2}\right)$ and chlorophyll content in both the years $2016 / 2017$ and 2017/2018, respectively. Highest plant heights were given by the plants at RZT-22 ${ }^{\circ} \mathrm{C}(136 \mathrm{~cm}$ and $184 \mathrm{~cm})$, followed by those at cooled RZT- $25^{\circ} \mathrm{C}(143.3 \mathrm{~cm}$ and $179.7 \mathrm{~cm})$ with high DO levels $(8.0 \mathrm{mg} / \mathrm{L}$ and $8.2 \mathrm{mg} / \mathrm{L})$ and $(7.0 \mathrm{mg} / \mathrm{L}$ and $7.2 \mathrm{mg} / \mathrm{L})$, whereas the lowest plant height was given by control-non-cooled RZT-33 ${ }^{\circ} \mathrm{C}(122.4 \mathrm{~cm}$ and $155 \mathrm{~cm}$ ) with lower DO levels $(5.0 \mathrm{mg} / \mathrm{L}$ and $5.0 \mathrm{mg} / \mathrm{L}$ ), respectively (Table 6). With regard to leaf number, leaf area and chlorophyll content similar trend was observed as the plants at cooled RZT-22 ${ }^{\circ} \mathrm{C}$ and cooled RZT-25 ${ }^{\circ} \mathrm{C}$ produced high leaf number, leaf area and chlorophyll content with higher DO levels in both the years 2016/2017 and 2017/2018, respectively (Table 6). 
Table 6. DO and growth parameters as affected by RZT of cucumber grown in hydroponic system in cooled greenhouse during fall cropping period (September-November)

\begin{tabular}{|c|c|c|c|c|c|c|c|c|c|c|}
\hline \multirow[b]{2}{*}{ RZT } & \multicolumn{5}{|c|}{ First Year 2016/2017 } & \multicolumn{5}{|c|}{ Second Year 2017/2018 } \\
\hline & $\begin{array}{l}\mathrm{DO} \\
\mathrm{mg} / \mathrm{L}\end{array}$ & $\begin{array}{l}\text { Plant } \\
\text { height } \mathrm{cm}\end{array}$ & $\begin{array}{l}\text { Leaf } \\
\text { number/plant }\end{array}$ & $\begin{array}{l}\text { Leaf } \\
\text { area } \mathrm{cm}^{2}\end{array}$ & $\begin{array}{l}\text { Chlorophyll } \\
\text { SPAD }\end{array}$ & $\begin{array}{l}\mathrm{DO} \\
\mathrm{mg} / \mathrm{L}\end{array}$ & $\begin{array}{l}\text { Plant } \\
\text { height } \mathrm{cm}\end{array}$ & $\begin{array}{l}\text { Leaf } \\
\text { number/plant }\end{array}$ & $\begin{array}{l}\text { Leaf } \\
\text { area } \mathrm{cm}^{2}\end{array}$ & $\begin{array}{l}\text { Chlorophyll } \\
\text { SPAD }\end{array}$ \\
\hline $22{ }^{\circ} \mathrm{C}$ & $8.0 \mathrm{a}$ & $136.0 \mathrm{~b}$ & $32 \mathrm{a}$ & $333.2 \mathrm{~b}$ & $49.7 \mathrm{a}$ & $8.2 \mathrm{a}$ & $184.0 \mathrm{a}$ & $40 \mathrm{a}$ & $334.2 \mathrm{a}$ & $48.0 \mathrm{a}$ \\
\hline $25^{\circ} \mathrm{C}$ & $7.0 \mathrm{~b}$ & $143.3 \mathrm{a}$ & $32 \mathrm{a}$ & $345.4 \mathrm{a}$ & $50.2 \mathrm{a}$ & $7.2 \mathrm{~b}$ & $179.7 \mathrm{a}$ & $40 \mathrm{a}$ & $342.2 \mathrm{a}$ & $47.4 \mathrm{a}$ \\
\hline $28^{\circ} \mathrm{C}$ & $5.5 \mathrm{c}$ & $131.7 \mathrm{c}$ & $30 \mathrm{~b}$ & $293.7 \mathrm{c}$ & $45.1 \mathrm{~b}$ & $5.5 \mathrm{c}$ & $155.1 \mathrm{~b}$ & $34 \mathrm{~b}$ & $295.6 \mathrm{~b}$ & $45.1 \mathrm{~b}$ \\
\hline $33^{\circ} \mathrm{C}$ & $5.0 \mathrm{~d}$ & $122.4 \mathrm{~d}$ & $29 \mathrm{c}$ & $286.4 \mathrm{~d}$ & $45.4 \mathrm{~b}$ & $5.0 \mathrm{~d}$ & $155.0 \mathrm{~b}$ & $33 \mathrm{~b}$ & $286.9 \mathrm{c}$ & $44.8 \mathrm{~b}$ \\
\hline \multicolumn{11}{|c|}{ Statistical Parameters } \\
\hline F-test & $* *$ & $* *$ & $* *$ & $* *$ & $* *$ & $* *$ & $* *$ & $* *$ & $* *$ & $* *$ \\
\hline $\operatorname{LSD}(5 \%)$ & 0.28 & 4.0 & 1.0 & 24.3 & 1.6 & 0.24 & 4.9 & 0.9 & 19.1 & 0.77 \\
\hline $\mathrm{CV} \%$ & 5.2 & 7.4 & 8.2 & 4.9 & 8.2 & 4.5 & 7.2 & 5.8 & 4.1 & 4.1 \\
\hline
\end{tabular}

\subsubsection{Yield Parameters}

Cooled nutrient solution temperature would influence oxygen level in the root-zone of cucumber with increased DO levels in nutrient solution which in turn increase the magnitude of yield parameters such as fruit number $/ \mathrm{m}^{2}$ and yield $\mathrm{kg} / \mathrm{m}^{2}$. Significant $(\mathrm{p}<0.05)$ effects were observed between cooled RZTs and control-uncooled RZT- $33{ }^{\circ} \mathrm{C}$ in DO levels, fruit number and yield $\mathrm{kg} / \mathrm{m}^{2}$ in both the years 2016/2017 and 2017/2018. Highest fruit number $/ \mathrm{m}^{2}$ were produced by the plants at cooled RZT-22 ${ }^{\circ} \mathrm{C}\left(201 / \mathrm{m}^{2}\right.$ and $\left.273 / \mathrm{m}^{2}\right)$ and cooled RZT- $25{ }^{\circ} \mathrm{C}$ $\left(209 / \mathrm{m}^{2}\right.$ and $\left.263 / \mathrm{m}^{2}\right)$ with high DO levels $(8.0 \mathrm{mg} / \mathrm{L}$ and $8.2 \mathrm{mg} / \mathrm{L})$ and $(7.0 \mathrm{mg} / \mathrm{L}$ and $7.2 \mathrm{mg} / \mathrm{L})$, while the lowest was given by control-non-cooled RZT- $33{ }^{\circ} \mathrm{C}\left(154 / \mathrm{m}^{2}\right.$ and $\left.217 / \mathrm{m}^{2}\right)$ with low DO levels $(5.0 \mathrm{mg} / \mathrm{L}$ and 5.0 $\mathrm{mg} / \mathrm{L}$ ) in the two years (Table 7). Highest yield were produced the plants at cooled RZT-22 ${ }^{\circ} \mathrm{C} 26.4 \mathrm{~kg} / \mathrm{m}^{2}$ and $31.8 \mathrm{~kg} / \mathrm{m}^{2}$ equivalent to $6.4 \mathrm{t} / \mathrm{gh}$ and $\left.8.5 \mathrm{t} / \mathrm{gh}\right)$ with higher DO levels $(8.0 \mathrm{mg} / \mathrm{L}$ and $8.2 \mathrm{mg} / \mathrm{L})$, followed by those at cooled RZT- $25{ }^{\circ} \mathrm{C}$ with $26.2 \mathrm{~kg} / \mathrm{m}^{2}$ and $32.6 \mathrm{~kg} / \mathrm{m}^{2}$ equivalent to $7.0 \mathrm{t} / \mathrm{gh}$ and $8.7 \mathrm{t} / \mathrm{gh}$ ) with higher DO levels $(7.0 \mathrm{mg} / \mathrm{L}$ and $7.2 \mathrm{mg} / \mathrm{L})$ and the lowest was produced by control-uncooled RZT- $33{ }^{\circ} \mathrm{C}\left(18.7 \mathrm{~kg} / \mathrm{m}^{2}\right.$ and $25.6 \mathrm{~kg} / \mathrm{m}^{2}$ equivalent to $5.0 \mathrm{t} / \mathrm{gh}$ and $6.8 \mathrm{t} / \mathrm{gh}$ ) with low DO levels $(5.0 \mathrm{mg} / \mathrm{L}, 5.0 \mathrm{mg} / \mathrm{L})$ in both years $2016 / 2017$ and 2017/2018 respectively (Table 7).

Table 7. DO and Production Parameters as affected by RZT of cucumber grown in hydroponic system in cooled greenhouse during fall cropping period (September-November) in cooled greenhouse

\begin{tabular}{|c|c|c|c|c|c|c|}
\hline \multirow{2}{*}{ RZT } & \multicolumn{3}{|c|}{ First year 2016/2017 } & \multicolumn{3}{|c|}{ Second year 2017/2018 } \\
\hline & $\mathrm{DO}_{2} \mathrm{mg} / \mathrm{L}$ & Fruit. $\mathrm{No} / \mathrm{m}^{2}$ & Yield t/gh & $\mathrm{DO}_{2} \mathrm{mg} / \mathrm{L}$ & Fruit. $\mathrm{No} / \mathrm{m}^{2}$ & Yield t/gh \\
\hline $22^{\circ} \mathrm{C}$ & $8.0 \mathrm{a}$ & $201 \mathrm{a}$ & $6.4 \mathrm{a}$ & $8.2 \mathrm{a}$ & $273 \mathrm{a}$ & $8.5 \mathrm{a}$ \\
\hline $25{ }^{\circ} \mathrm{C}$ & $7.3 \mathrm{~b}$ & $209 \mathrm{a}$ & $7.0 \mathrm{a}$ & $7.2 \mathrm{~b}$ & $263 \mathrm{a}$ & $8.7 \mathrm{a}$ \\
\hline $28^{\circ} \mathrm{C}$ & $5.5 \mathrm{c}$ & $184 \mathrm{~b}$ & $6.0 \mathrm{ab}$ & $5.5 \mathrm{c}$ & $219 \mathrm{~b}$ & $7.0 \mathrm{~b}$ \\
\hline $33^{\circ} \mathrm{C}$ & $5.0 \mathrm{~d}$ & $153 \mathrm{~b}$ & $5.0 \mathrm{~b}$ & $5.0 \mathrm{~d}$ & $217 \mathrm{~b}$ & $6.8 \mathrm{~b}$ \\
\hline \multicolumn{7}{|c|}{ Statistical Parameters } \\
\hline F-test & ** & ** & ** & $* *$ & ** & ** \\
\hline $\operatorname{LSD}(5 \%)$ & 0.28 & 28.8 & 1.23 & 0.24 & 34 & 1.1 \\
\hline $\mathrm{CV} \%$ & 5.2 & 10.0 & 13.2 & 4.5 & 9.1 & 9.3 \\
\hline
\end{tabular}

\subsubsection{Quality Attributes}

Fruit length and fruit diameters and total soluble solids percentage as brix of cucumber were not affected by cooled temperature despite increase in the levels of DO in the first year 2016/2017, whereas the differences were significant $(\mathrm{p}<0.05)$ only in fruit diameter between the cooled RZTs and non-cooled RZT- $33{ }^{\circ} \mathrm{C}$ in the second year 2017/2018 (Table 8). 
Table 8. DO and Quality attributes as affected by RZT of cucumber grown in hydroponic system in cooled greenhouse during fall cropping period (September-November) in cooled greenhouse

\begin{tabular}{|c|c|c|c|c|c|c|c|c|}
\hline \multirow[b]{2}{*}{ RZT } & \multicolumn{4}{|c|}{ First year 2016/2017 } & \multicolumn{4}{|c|}{ Second year 2017/2018 } \\
\hline & $\begin{array}{l}\mathrm{DO} \\
\mathrm{mg} / \mathrm{L}\end{array}$ & $\begin{array}{l}\text { Fruit } \\
\text { length cm }\end{array}$ & $\begin{array}{l}\text { Fruit } \\
\text { diameter } \mathrm{cm}\end{array}$ & $\begin{array}{l}\text { Total soluble } \\
\text { solids (\%) }\end{array}$ & $\begin{array}{l}\mathrm{DO} \\
\mathrm{mg} / \mathrm{L}\end{array}$ & $\begin{array}{l}\text { Fruit } \\
\text { length } \mathrm{cm}\end{array}$ & $\begin{array}{l}\text { Fruit } \\
\text { diameter } \mathrm{cm}\end{array}$ & $\begin{array}{l}\text { Total soluble } \\
\text { solids (\%) }\end{array}$ \\
\hline $22^{\circ} \mathrm{C}$ & $8.0 \mathrm{a}$ & $14.3 \mathrm{a}$ & $3.3 \mathrm{a}$ & $3.7 \mathrm{a}$ & $8.2 \mathrm{a}$ & $14.5 \mathrm{a}$ & $3.4 \mathrm{ab}$ & $3.1 \mathrm{a}$ \\
\hline $25^{\circ} \mathrm{C}$ & $7.3 \mathrm{~b}$ & $14.5 \mathrm{a}$ & $3.4 \mathrm{a}$ & $3.6 \mathrm{a}$ & $7.2 \mathrm{~b}$ & $14.4 \mathrm{a}$ & $3.3 \mathrm{~b}$ & $2.8 \mathrm{a}$ \\
\hline $28^{\circ} \mathrm{C}$ & $5.5 \mathrm{c}$ & $14.3 \mathrm{a}$ & $3.3 \mathrm{a}$ & $3.5 \mathrm{a}$ & $5.5 \mathrm{c}$ & $14.6 \mathrm{a}$ & $3.5 \mathrm{a}$ & $2.8 \mathrm{a}$ \\
\hline $33^{\circ} \mathrm{C}$ & $5.0 \mathrm{~d}$ & $14.2 \mathrm{a}$ & $3.3 \mathrm{a}$ & $4.0 \mathrm{a}$ & $5.0 \mathrm{~d}$ & $14.1 \mathrm{a}$ & $3.3 \mathrm{~b}$ & $3.0 \mathrm{a}$ \\
\hline \multicolumn{9}{|c|}{ Statistical Parameters } \\
\hline F-test & $* *$ & NS & NS & NS & $* *$ & NS & $* *$ & NS \\
\hline $\operatorname{LSD}(5 \%)$ & 0.28 & 0.94 & 0.24 & 0.6 & 0.24 & 0.5 & 0.16 & 0.5 \\
\hline $\mathrm{CV} \%$ & 5.2 & 2.9 & 6.4 & 8.0 & 4.5 & 3.1 & 3.2 & 6.4 \\
\hline
\end{tabular}

\subsection{Spring Cropping Period (February-May)}

\subsubsection{Nutrient Solution Dissolved Oxygen Levels}

Significant $(\mathrm{p}<0.05)$ differences were recorded in DO levels between nutrient solution temperatures (NST) at different times in both the years 2016/2017 and 2017/2018 in cucumber. High DO levels were recoded at 8 am $(8.5 \mathrm{mg} / \mathrm{L}, 8.6 \mathrm{mg} / \mathrm{L}, 7.6 \mathrm{mg} / \mathrm{L}$ and $7.7 \mathrm{mg} / \mathrm{L})$ morning and at $12 \mathrm{pm}(7.8 \mathrm{mg} / \mathrm{L}, 8.2 \mathrm{mg} / \mathrm{L}, 7.2 \mathrm{mg} / \mathrm{L}$ and 7.4 $\mathrm{mg} / \mathrm{L}$ ) in cooled NST-22 ${ }^{\circ} \mathrm{C}$ and cooled NST-25 ${ }^{\circ} \mathrm{C}$ respectively, while the lowest was recoded at control-non-cooled NTS-33 ${ }^{\circ} \mathrm{C}$ with linear $\mathrm{R}^{2}$ of $0.92,0.96,0.91$ and 0.94 in both the years $2016 / 2017$ and 2017/2018, respectively (Figures 9a and 9b). Higher levels of DO were found with cooled NST-22 ${ }^{\circ} \mathrm{C}(7.9 \mathrm{mg} / \mathrm{L}$ and $8.3 \mathrm{mg} / \mathrm{L})$, followed by cooled NST- $25{ }^{\circ} \mathrm{C}(7.3 \mathrm{mg} / \mathrm{L}$ and $7.4 \mathrm{mg} / \mathrm{L})$ with significant $(\mathrm{p}<0.05)$ differences between control-non-cooled NST-33 ${ }^{\circ} \mathrm{C}$, which recorded the lowest DO levels $(5.7 \mathrm{mg} / \mathrm{L}$ and $5.8 \mathrm{mg} / \mathrm{L})$ with linear $\mathrm{R}^{2}$ of 0.93 and 0.97 in the two years 2016/2017 and 2017/2018, respectively (Figures 10a and 10b).

\subsubsection{Dissolved Oxygen Levels in Drain Nutrient Solution}

Significant $(p<0.05)$ effects were observed in DO levels of drain nutrient solution between RZT at different times in both the years 2016/2017 and 2017/2018 in cucumber. Higher DO levels were found at $8 \mathrm{am}(3.6 \mathrm{mg} / \mathrm{L}$, $3.5 \mathrm{mg} / \mathrm{L}, 3.4 \mathrm{mg} / \mathrm{L}$ and $3.2 \mathrm{mg} / \mathrm{L})$ morning and at $12 \mathrm{pm}(3.5 \mathrm{mg} / \mathrm{L}, 3.4 \mathrm{mg} / \mathrm{L}, 3.3 \mathrm{mg} / \mathrm{L}$ and $3.1 \mathrm{mg} / \mathrm{L})$ in cooled RZT- $22{ }^{\circ} \mathrm{C}$ and cooled RZT- $25{ }^{\circ} \mathrm{C}$, respectively compared to control-non-cooled RZT- $33{ }^{\circ} \mathrm{C}$ with linear $\mathrm{R}^{2}$ of $0.92,0.99,0.95$ and 0.99 in both the years 2016/2017 and 2017/2018, respectively (Figures 11a and 11b). Higher levels of DO levels in drain NST were recorded with cooled RZT-22 ${ }^{\circ} \mathrm{C}(3.5 \mathrm{mg} / \mathrm{L}$ and $3.4 \mathrm{mg} / \mathrm{L})$, followed by cooled RZT-25 ${ }^{\circ} \mathrm{C}(3.3 \mathrm{mg} / \mathrm{L}$ and $3.1 \mathrm{mg} / \mathrm{L})$ with significant $(\mathrm{p}<0.05)$ differences between control-non-cooled RZT-33 ${ }^{\circ} \mathrm{C}$, which gave the lowest $(2.3 \mathrm{mg} / \mathrm{L}$ and $2.2 \mathrm{mg} / \mathrm{L})$ with linear $\mathrm{R}^{2}$ of 0.95 and 0.99 in the two years 2016/2017 and 2017/2018, respectively (Figures 12a and 12b).

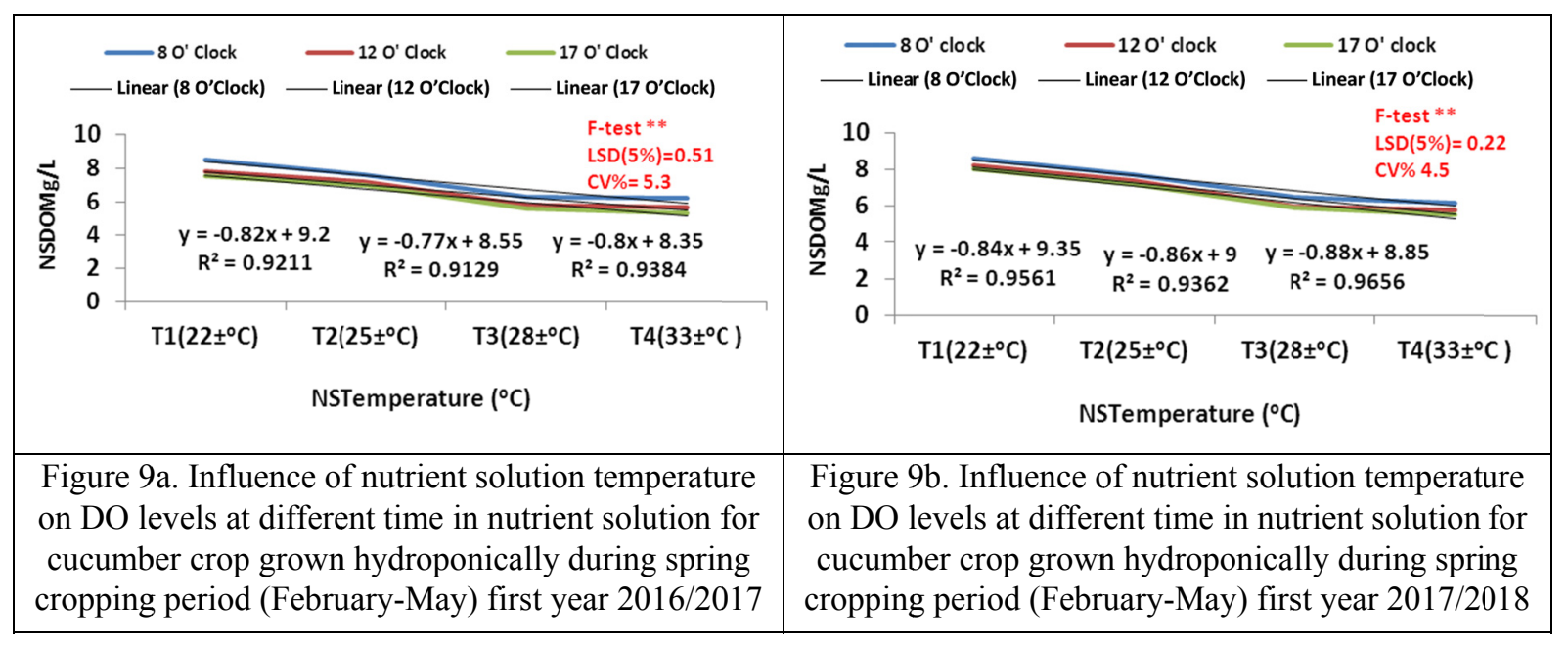




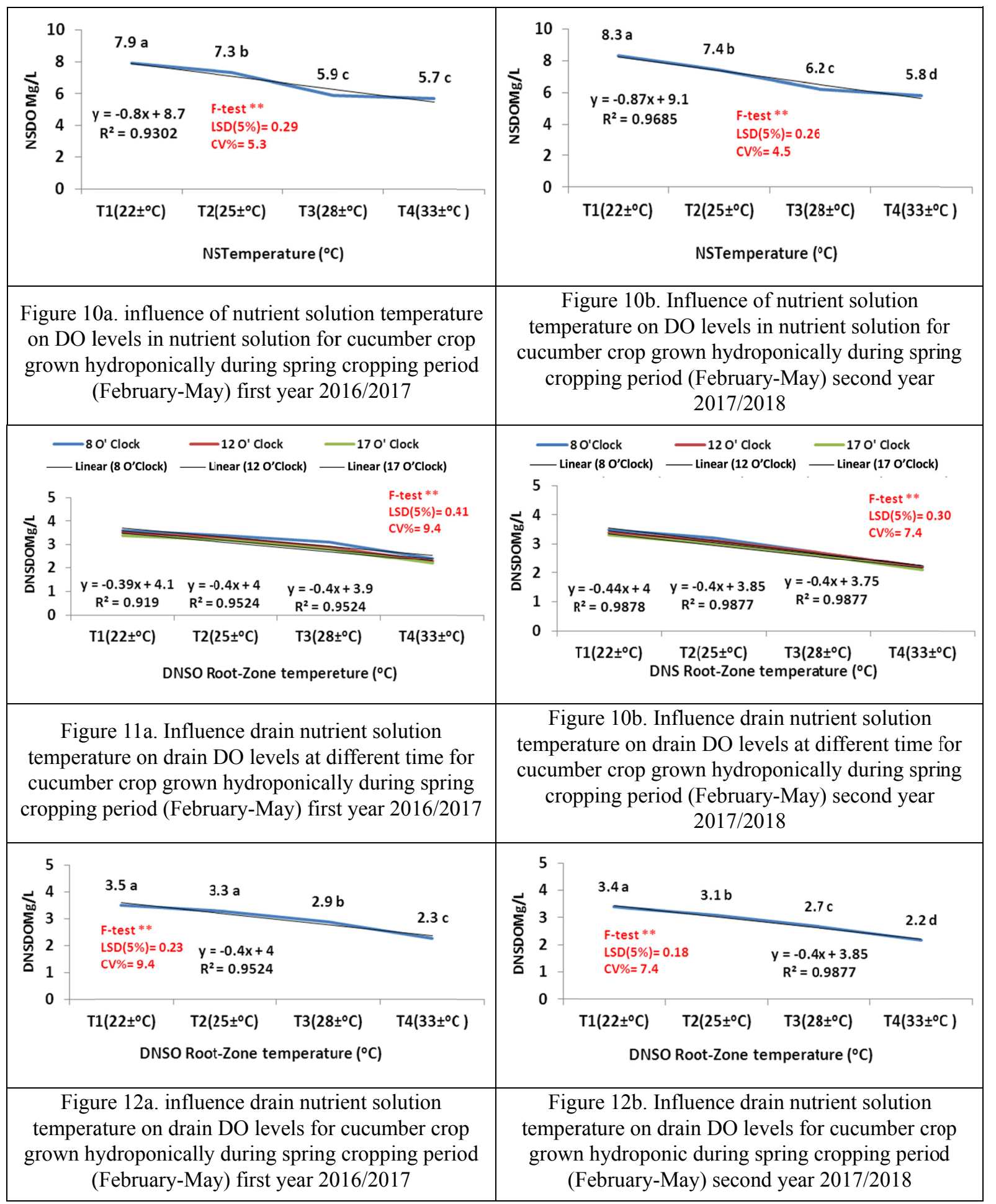

\subsubsection{Dissolved Oxygen Consumption}

Significant $(\mathrm{p}<0.05)$ differences were revealed in DO consumption by roots between the root-zone temperatures in both the years $2016 / 2017$ and $2017 / 2018$. Oxygen consumption by the roots of cucumber ranged from 3.0 $\mathrm{mg} / \mathrm{L}$ to $4.4 \mathrm{mg} / \mathrm{L}$ in first year $2016 / 2017$ and from $3.5 \mathrm{mg} / \mathrm{L}$ to $4.9 \mathrm{mg} / \mathrm{L}$ in the second year $2017 / 2018$. Higher oxygen consumption by the roots were recorded with cooled RZT- $22{ }^{\circ} \mathrm{C}(4.4 \mathrm{mg} / \mathrm{L}$ and $4.9 \mathrm{mg} / \mathrm{L})$, followed by cooled RZT- $25^{\circ} \mathrm{C}(4.0 \mathrm{mg} / \mathrm{L}$ and $4.3 \mathrm{mg} / \mathrm{L})$, while the lowest was given by cooled RZT- $28^{\circ} \mathrm{C}(3.0 \mathrm{mg} / \mathrm{L}$ and 3.5 $\mathrm{mg} / \mathrm{L}$ ) in both the years 2016/2017 and 2017/2018 (Table 9). 
Table 9. Oxygen $\left(\mathrm{O}_{2}\right)$ input, output and consumption of cucumber crop at four RZT grown in hydroponic closed system during spring cropping period (February-May) in cooled greenhouse

\begin{tabular}{|c|c|c|c|c|c|c|}
\hline \multirow[b]{2}{*}{ RZT } & \multicolumn{3}{|c|}{ First year 2016/2017 } & \multicolumn{3}{|c|}{ Second year 2017/2018 } \\
\hline & $\begin{array}{l}\text { DO mg/L } \\
\text { input }\end{array}$ & $\begin{array}{l}\text { DO mg/L } \\
\text { output }\end{array}$ & $\begin{array}{l}\mathrm{DO} \mathrm{mg} / \mathrm{L} \\
\text { consumption }\end{array}$ & $\begin{array}{l}\text { DO mg/L } \\
\text { input }\end{array}$ & $\begin{array}{l}\text { DO mg/L } \\
\text { output }\end{array}$ & $\begin{array}{l}\text { DO mg/L } \\
\text { consumption }\end{array}$ \\
\hline $22{ }^{\circ} \mathrm{C}$ & $7.9 \mathrm{a}$ & $3.5 \mathrm{a}$ & $4.4 \mathrm{a}$ & $8.3 \mathrm{a}$ & $3.4 \mathrm{a}$ & $4.9 \mathrm{a}$ \\
\hline $25^{\circ} \mathrm{C}$ & $7.3 \mathrm{~b}$ & $3.3 \mathrm{a}$ & $4.0 \mathrm{~b}$ & $7.4 \mathrm{~b}$ & $3.1 \mathrm{~b}$ & $4.3 \mathrm{~b}$ \\
\hline $28{ }^{\circ} \mathrm{C}$ & $5.9 \mathrm{c}$ & $2.9 \mathrm{~b}$ & $3.0 \mathrm{~d}$ & $6.2 \mathrm{c}$ & $2.7 \mathrm{c}$ & $3.5 \mathrm{c}$ \\
\hline $33^{\circ} \mathrm{C}$ & $5.7 \mathrm{c}$ & $2.3 \mathrm{c}$ & $3.4 \mathrm{c}$ & $5.8 \mathrm{~d}$ & $2.2 \mathrm{~d}$ & $3.6 \mathrm{c}$ \\
\hline \multicolumn{7}{|c|}{ Statistical Parameters } \\
\hline F-test & $* *$ & $* *$ & $* *$ & $* *$ & $* *$ & $* *$ \\
\hline $\operatorname{LSD}(5 \%)$ & 0.29 & 0.23 & 0.39 & 0.26 & 0.18 & 0.34 \\
\hline $\mathrm{CV} \%$ & 5.3 & 9.4 & 12.9 & 4.5 & 7.4 & 10.1 \\
\hline
\end{tabular}

\subsubsection{Growth Parameters}

The increase in DO levels at cool root zones were found to influence in the growth parameters such as plant height, leaf number, leaf area and chlorophyll content of cucumber. The results showed significant $(p<0.05)$ differences between the cooled RZTs and control-uncooled RZT-33 ${ }^{\circ} \mathrm{C}$ in plant height $(\mathrm{cm})$, leaf number, leaf area $\left(\mathrm{cm}^{2}\right)$ and chlorophyll content in both the years 2016/2017 and 2017/2018, respectively. Higher plant height were produced by cooled RZT- $22{ }^{\circ} \mathrm{C}(150.6 \mathrm{~cm}$ and $155.3 \mathrm{~cm})$, followed by cooled RZT- $25{ }^{\circ} \mathrm{C}(157.1 \mathrm{~cm}$ and $153.3 \mathrm{~cm}$ ) with high DO levels $(7.9 \mathrm{mg} / \mathrm{L}$ and $8.3 \mathrm{mg} / \mathrm{L})$ and $(7.3 \mathrm{mg} / \mathrm{L}$ and $7.4 \mathrm{mg} / \mathrm{L})$, whereas the lowest plant height was given by control-uncooled RZT-33 ${ }^{\circ} \mathrm{C}(138.4 \mathrm{~cm}$ and $143.3 \mathrm{~cm})$ with low DO levels $(5.7 \mathrm{mg} / \mathrm{L}$ and $5.8 \mathrm{mg} / \mathrm{L}$ ) respectively (Table 10). With respect to leaf number, leaf area and chlorophyll content the same trend were observed as that in plant height. The cooled RZT- $22{ }^{\circ} \mathrm{C}$ and cooled RZT- $25{ }^{\circ} \mathrm{C}$ produced higher leaf number, leaf area and chlorophyll content with high DO levels in both the years 2016/2017 and 2017/2018, respectively (Table 10).

Table10. DO and growth parameters as affected by RZT of cucumber grown in hydroponic system in cooled greenhouse during spring cropping period (February-May) in cooled greenhouse

\begin{tabular}{|c|c|c|c|c|c|c|c|c|c|c|}
\hline \multirow[b]{2}{*}{ RZT } & \multicolumn{5}{|c|}{ First Year 2016/2017 } & \multicolumn{5}{|c|}{ Second Year 2017/2018 } \\
\hline & $\begin{array}{l}\mathrm{DO} \\
\mathrm{mg} / \mathrm{L}\end{array}$ & $\begin{array}{l}\text { Plant } \\
\text { height } \mathrm{cm}\end{array}$ & $\begin{array}{l}\text { Leaf } \\
\text { number/plant }\end{array}$ & $\begin{array}{l}\text { Leaf } \\
\text { area } \mathrm{cm}^{2}\end{array}$ & $\begin{array}{l}\text { Chlorophyll } \\
\text { SPAD }\end{array}$ & $\begin{array}{l}\mathrm{DO} \\
\mathrm{mg} / \mathrm{L}\end{array}$ & $\begin{array}{l}\text { Plant } \\
\text { height } \mathrm{cm}\end{array}$ & $\begin{array}{l}\text { Leaf } \\
\text { number/plant }\end{array}$ & $\begin{array}{l}\text { Leaf } \\
\text { area } \mathrm{cm}^{2}\end{array}$ & $\begin{array}{l}\text { Chlorophyll } \\
\text { SPAD }\end{array}$ \\
\hline $22{ }^{\circ} \mathrm{C}$ & $7.9 \mathrm{a}$ & $150.6 \mathrm{~b}$ & $32 \mathrm{a}$ & $372.3 \mathrm{a}$ & $47.1 \mathrm{a}$ & $8.3 \mathrm{a}$ & $155.3 \mathrm{a}$ & $25 \mathrm{a}$ & $389.1 \mathrm{a}$ & $46.3 \mathrm{a}$ \\
\hline $25^{\circ} \mathrm{C}$ & $7.3 \mathrm{~b}$ & $157.1 \mathrm{a}$ & $32 \mathrm{a}$ & $372.3 \mathrm{a}$ & $47.4 \mathrm{a}$ & $7.4 \mathrm{~b}$ & $153.3 \mathrm{a}$ & $24 \mathrm{ab}$ & $373.4 \mathrm{a}$ & $46.0 \mathrm{a}$ \\
\hline $28^{\circ} \mathrm{C}$ & $5.9 \mathrm{c}$ & $141.2 \mathrm{c}$ & $27 \mathrm{~b}$ & $336.8 \mathrm{ab}$ & $42.9 \mathrm{c}$ & $6.2 \mathrm{c}$ & $143.4 \mathrm{~b}$ & $23 \mathrm{~b}$ & $306.4 \mathrm{~b}$ & $44.9 \mathrm{~b}$ \\
\hline $33{ }^{\circ} \mathrm{C}$ & $5.7 \mathrm{~d}$ & $138.4 d$ & $27 \mathrm{~b}$ & $323.7 \mathrm{~b}$ & $43.9 \mathrm{~b}$ & $5.8 \mathrm{~d}$ & $143.3 \mathrm{~b}$ & $23 \mathrm{~b}$ & $297.0 \mathrm{~b}$ & $44.6 \mathrm{~b}$ \\
\hline \multicolumn{11}{|c|}{ Statistical Parameters } \\
\hline F-test & $* *$ & $* *$ & $* *$ & $* *$ & $* *$ & $* *$ & $* *$ & $* *$ & $* *$ & $* *$ \\
\hline $\operatorname{LSD}(5 \%)$ & 0.29 & 4.5 & 0.7 & 37.1 & 0.9 & 0.26 & 7.3 & 1.1 & 23.6 & 1.1 \\
\hline $\mathrm{CV} \%$ & 5.3 & 7.0 & 5.2 & 6.9 & 4.4 & 4.5 & 11.1 & 10.6 & 4.5 & 5.3 \\
\hline
\end{tabular}

\subsubsection{Yield Parameters}

Cooled nutrient solution temperature was found to influence DO levels in the root-zone of cucumber which in turn influenced positively the yield parameters such as fruit number $/ \mathrm{m}^{2}$ and yield $\mathrm{kg} / \mathrm{m}^{2}$. Significant $(\mathrm{p}<0.05)$ effects were observed between cooled RZTs and control-non-cooled RZT- $33{ }^{\circ} \mathrm{C}$ in fruit number and yield $\mathrm{kg} / \mathrm{m}^{2}$ with high DO levels in both the years 2016/2017 and 2017/2018. Higher fruit number $/ \mathrm{m}^{2}$ were produced by cooled RZT-22 ${ }^{\circ} \mathrm{C}\left(241 / \mathrm{m}^{2}\right.$ and $\left.283 / \mathrm{m}^{2}\right)$ and cooled RZT-25 ${ }^{\circ} \mathrm{C}\left(253 / \mathrm{m}^{2}\right.$ and $\left.253 / \mathrm{m}^{2}\right)$ with high DO levels $(7.9$ $\mathrm{mg} / \mathrm{L}$ and $8.3 \mathrm{mg} / \mathrm{L})$ and $(7.3 \mathrm{mg} / \mathrm{L}$ and $7.4 \mathrm{mg} / \mathrm{L})$, while the lowest was given by control-uncooled RZT- $33{ }^{\circ} \mathrm{C}$ $\left(197 / \mathrm{m}^{2}\right.$ and $\left.216 / \mathrm{m}^{2}\right)$ with low DO levels $(5.7 \mathrm{mg} / \mathrm{L}$ and $5.8 \mathrm{mg} / \mathrm{L})$ in the two years $2016 / 2017$ and 2017/2018, respectively (Table 11). High yields were given the plants at cooled RZT-22 ${ }^{\circ} \mathrm{C}$ to the extent of $\left(28.8 \mathrm{~kg} / \mathrm{m}^{2}\right.$ and $32 \mathrm{~kg} / \mathrm{m}^{2}$ equivalent to $7.7 \mathrm{t} / \mathrm{gh}$ and $8.5 \mathrm{t} / \mathrm{gh}$ ) with higher DO levels $(7.9 \mathrm{mg} / \mathrm{L}$ and $8.3 \mathrm{mg} / \mathrm{L})$, followed by those plants at cooled RZT- $25{ }^{\circ} \mathrm{C}$ with yields of $\left(29.8 \mathrm{~kg} / \mathrm{m}^{2}\right.$ and $28.6 \mathrm{~kg} / \mathrm{m}^{2}$ equivalent to $\left.8.0 \mathrm{t} / \mathrm{gh}, 7.6 \mathrm{t} / \mathrm{gh}\right)$ with higher 
DO levels $(7.3 \mathrm{mg} / \mathrm{L}$ and $7.4 \mathrm{mg} / \mathrm{L})$ and the lowest was produced by control-uncooled RZT- $33{ }^{\circ} \mathrm{C}\left(21.1 \mathrm{~kg} / \mathrm{m}^{2}\right.$ and $24.4 \mathrm{~kg} / \mathrm{m}^{2}$ equivalent to $(5.6 \mathrm{t} / \mathrm{gh}$ and $6.5 \mathrm{t} / \mathrm{gh})$ with low DO levels $(5.7 \mathrm{mg} / \mathrm{L}, 5.8 \mathrm{mg} / \mathrm{L})$ in both the years 2016/2017 and 2017/2018, respectively (Table 11).

Table11. DO and yield parameters as affected by RZT of cucumber grown in hydroponic system in cooled greenhouse during spring cropping period (February-May) in cooled greenhouse

\begin{tabular}{|c|c|c|c|c|c|c|}
\hline \multirow{2}{*}{ RZT } & \multicolumn{3}{|c|}{ First year 2016/2017 } & \multicolumn{3}{|c|}{ Second year 2017/2018 } \\
\hline & $\mathrm{DO} \mathrm{mg} / \mathrm{L}$ & Fruit. $\mathrm{No} / \mathrm{m}^{2}$ & Yield t/gh & $\mathrm{DO} \mathrm{mg} / \mathrm{L}$ & Fruit. $\mathrm{No} / \mathrm{m}^{2}$ & Yield t/gh \\
\hline $22{ }^{\circ} \mathrm{C}$ & $7.9 \mathrm{a}$ & $241 \mathrm{a}$ & $7.7 \mathrm{a}$ & $8.3 \mathrm{a}$ & $283 \mathrm{a}$ & $8.5 \mathrm{a}$ \\
\hline $25^{\circ} \mathrm{C}$ & $7.3 \mathrm{~b}$ & $153 \mathrm{a}$ & $8.0 \mathrm{a}$ & $7.4 \mathrm{~b}$ & $253 \mathrm{ab}$ & $7.6 \mathrm{ab}$ \\
\hline $28^{\circ} \mathrm{C}$ & $5.9 \mathrm{c}$ & $196 \mathrm{a}$ & $5.8 \mathrm{~b}$ & $6.2 \mathrm{c}$ & $237 \mathrm{bc}$ & $7.1 \mathrm{ab}$ \\
\hline $33{ }^{\circ} \mathrm{C}$ & $5.7 \mathrm{~d}$ & $197 \mathrm{~b}$ & $8.6 \mathrm{~b}$ & $5.8 \mathrm{~d}$ & $216 \mathrm{c}$ & $6.5 \mathrm{~b}$ \\
\hline \multicolumn{7}{|c|}{ Statistical Parameters } \\
\hline F-test & $* *$ & $* *$ & $* *$ & $* *$ & $* *$ & $* *$ \\
\hline LSD (5\%) & 0.29 & 36 & 1.24 & 0.26 & 35 & 1.4 \\
\hline $\mathrm{CV} \%$ & 5.3 & 10.6 & 11.9 & 4.5 & 9.3 & 12.0 \\
\hline
\end{tabular}

\subsubsection{Quality Attributes}

No significant differences were observed between cooled RZTs and control-non-cooled RZT-33 ${ }^{\circ} \mathrm{C}$ in fruit length and total soluble solid percentages however, increased DO levels did not affect fruit length and total soluble solids percentage of cucumber fruits, whereas fruit diameter was found to have significant effect with cooled RZTs and control-uncooled RZT with DO levels in the first year 2016/2017 (Table 12). Higher fruits diameter was given by cooled RZT- $25{ }^{\circ} \mathrm{C}(3.5 \mathrm{~cm})$ with DO level $(7.3 \mathrm{mg} / \mathrm{L})$, followed by cooled RZT- $22{ }^{\circ} \mathrm{C}$ $(3.4 \mathrm{~cm})$ with DO level $(7.9 \mathrm{mg} / \mathrm{L})$, while the lowest was given by cooled RZT- $28^{\circ} \mathrm{C}(3.2 \mathrm{~cm})$ with D level $(5.9$ $\mathrm{mg} / \mathrm{L})$. Similarly higher total soluble solids were given by control-uncooled RZT-33 ${ }^{\circ} \mathrm{C}(3.9 \%)$ with DO levels $(5.7 \mathrm{mg} / \mathrm{L})$ in the first year 2016/2017 (Table 12). With respect to the second year 2017/2018, no significant differences were obtained in fruit length, fruit diameter and total soluble solids percentage between cooled RZTs and control-non-cooled RZT (Table 12).

Table12. DO and Quality Attributes as affected by RZT of cucumber grown in hydroponic system during spring cropping period (February-May) in cooled greenhouse

\begin{tabular}{|c|c|c|c|c|c|c|c|c|}
\hline \multirow[b]{2}{*}{ RZT } & \multicolumn{4}{|c|}{ First year 2016/2017 } & \multicolumn{4}{|c|}{ Second year 2017/2018 } \\
\hline & $\begin{array}{l}\mathrm{DO} \\
\mathrm{mg} / \mathrm{L}\end{array}$ & $\begin{array}{l}\text { Fruit } \\
\text { length } \mathrm{cm}\end{array}$ & $\begin{array}{l}\text { Fruit } \\
\text { diameter } \mathrm{cm}\end{array}$ & $\begin{array}{l}\text { Total soluble } \\
\text { solids }(\%)\end{array}$ & $\begin{array}{l}\mathrm{DO} \\
\mathrm{mg} / \mathrm{L}\end{array}$ & $\begin{array}{l}\text { Fruit } \\
\text { length } \mathrm{cm}\end{array}$ & $\begin{array}{l}\text { Fruit } \\
\text { diameter } \mathrm{cm}\end{array}$ & $\begin{array}{l}\text { Total soluble } \\
\text { solids }(\%)\end{array}$ \\
\hline $22{ }^{\circ} \mathrm{C}$ & $7.9 \mathrm{a}$ & $16.5 \mathrm{a}$ & $3.4 \mathrm{ab}$ & $3.8 \mathrm{a}$ & $8.3 \mathrm{a}$ & $15.4 \mathrm{a}$ & $3.4 \mathrm{a}$ & $3.2 \mathrm{a}$ \\
\hline $25^{\circ} \mathrm{C}$ & $7.3 \mathrm{~b}$ & $16.8 \mathrm{a}$ & $3.5 \mathrm{a}$ & $3.6 \mathrm{a}$ & $7.4 \mathrm{~b}$ & $15.4 \mathrm{a}$ & $3.4 \mathrm{a}$ & $3.0 \mathrm{a}$ \\
\hline $28^{\circ} \mathrm{C}$ & $5.9 \mathrm{c}$ & 16.6 & $3.2 \mathrm{~b}$ & $3.6 \mathrm{a}$ & $6.2 \mathrm{c}$ & $14.8 \mathrm{a}$ & $3.3 \mathrm{a}$ & $3.1 \mathrm{a}$ \\
\hline $33^{\circ} \mathrm{C}$ & $5.7 \mathrm{~d}$ & 16.2 & $3.3 \mathrm{ab}$ & $3.9 \mathrm{a}$ & $5.8 \mathrm{~d}$ & $15.3 \mathrm{a}$ & $3.2 \mathrm{a}$ & $3.3 \mathrm{a}$ \\
\hline \multicolumn{9}{|c|}{ Statistical Parameters } \\
\hline F-test & $* *$ & NS & $* *$ & NS & $* *$ & NS & NS & NS \\
\hline $\operatorname{LSD}(5 \%)$ & 0.29 & 0.9 & 0.24 & 0.4 & 0.26 & 0.74 & 0.21 & 0.28 \\
\hline $\mathrm{CV} \%$ & 5.3 & 5.0 & 4.7 & 6.1 & 4.5 & 3.2 & 4.1 & 5.8 \\
\hline
\end{tabular}

\section{Discussion}

\subsection{Nutrient Solution Dissolved Oxygen Levels}

Information regarding the influence of NST and its effect on solution oxygen levels in hydroponic system during high temperature season is limiting in literatures. Plants cannot survive without oxygen $\left(\mathrm{O}_{2}\right)$ especially in hydroponic systems for roots respirations, water and nutrient uptake. DO concentration in the root-zone nutrient solution is mainly controlled by factors such as temperature, partial atmospheric $\mathrm{O}_{2}$ pressure and salt concentrations (Zheng et al., 1993). The previous studies about oxygen content in nutrient solution have shown that inadequate aeration may cause waterlogging in the roots of many plants; and that sufficient forced aeration 
may be very expensive (Zeroni et al., 1983). It is known that while oxygen concentration in the nutrient solution is a limited factor (Adam, 2002; Morard et al., 2000; Zeroni et al., 1983), the availability of oxygen in the root zone is a critical factor in plant growth. Poorly aerated root zone is characterized by low oxygen and high carbon dioxide atmosphere (Glinski \& Stepniewski, 1985). Moreover, the oxygen limitation results in a reduction of water and nutrients uptake (Janick 1979; Glinski \& Stepniewski, 1985). Holtman et al. (2005), which affects the growth and development of the plant. The results of the present experiments have shown that nutrient solution exposure to cooled temperature $22{ }^{\circ} \mathrm{C}$ and $25^{\circ} \mathrm{C}$ had significantly $(\mathrm{p}<0.05)$ higher DO levels at 8 am and $12 \mathrm{pm}$ with linear regression $\mathrm{R}^{2}$ than control-uncooled nutrient solution in all cropping periods (June-August, September-November and February-May) in both the years 2016/2017 and 2017/2018 (Figures 1a, 1b, 5a, 5b, 9a and 9b). Urrestarazu and Mazuela (2005) illustrated that high oxygen content in nutrient solution tank was at 10 hrs and $17 \mathrm{hrs}$ for tomato in summer period and cucumber in fall period of crop. Lenzi et al. (2011) indicated in their Spanich experiment that aeration kept oxygen concentration at $7-8 \mathrm{mg} \mathrm{L}^{-1}$ while in the non aerated solution oxygen decreased gradually reaching at harvest with values of $1.92 \mathrm{mg} / \mathrm{L}$ and $2.83 \mathrm{mg} / \mathrm{L}$ in summer and autumn respectively. In the present experiment, high DO levels were recorded with NST-22 ${ }^{\circ} \mathrm{C}$ and NST- $25{ }^{\circ} \mathrm{C}$ in all cropping periods (June-August, September-November and February-May) although no any oxygen treatment was used it was ambient oxygen in the feeding tanks however, results of cropping period (June-August) showed more DO followed by cropping period (September-November) and the lowest was at non cooled NST-33C control in all cropping periods (Figures 2a, 2b, 6a, 6b, 10a and 10b). Our findings are in agreement with Holtman et al. (2005) who indicated that $3.5 \mathrm{mg} / \mathrm{L}$ DO represent a critical level, meaning that below these concentrations reduction of metabolic processes inside root cells may occur, resulting in reduced roots activity. Savvas and Passon (2002) reported that in closed hydroponic system with a low water or substrate volume, there were rise water temperatures during summer which may lead to oxygen deficiency due to reduced oxygen solubility and more rapid use by microorganisms and roots. Falah et al. (2010) found that in high solution temperature $\left(35^{\circ} \mathrm{C}\right)$ produced effects in the short and long-term. In the short-term, water and nutrients uptake were activated through a decrease in water viscosity, and membrane transport was affected. In the long term, oxygen solubility was reduced. Also Graves (1983) found that at temperatures below $22{ }^{\circ} \mathrm{C}$ the DO in the nutrient solution is sufficient to cover the demand of this element in tomato plants. Conversely, temperatures over $22{ }^{\circ} \mathrm{C}$, oxygen demand are not covered by the nutrient solution as higher temperatures increase the diffusion gas. Holtman et al. (2005) indicated that during the day oxygen levels in the irrigation system were high just after refreshment of the nutrient solution.

\subsection{Dissolved Oxygen Levels in Drain Nutrient Solution}

The amount of DO which gets depleted from the returned solution reflected to amount of oxygen taken by the roots of cucumber as respiration. Davis et al. (2010) found that oxygen concentrations decreased even further to virtually ambient levels when measured in the drain water or in the substrate reservoir. In our present results cooled nutrient solution temperature of NST- $22{ }^{\circ} \mathrm{C}$, NST- $25{ }^{\circ} \mathrm{C}$ and NST- $28{ }^{\circ} \mathrm{C}$ gave higher drain DO level with linear regression $\mathrm{R}^{2}$ at 8 am and $12 \mathrm{pm}$ than control-non-cooled NST-33C (Figures 3a, 3b, 7a, 7b, 11a and 11b). Our findings are in line with Urrestarazu and Mazuela (2005) who illustrated that high drain oxygen was at 10 hrs and 17 hrs for tomato in summer and for cucumber in fall. Bonachela et al. (2010) reported that average seasonal percentages of leached nutrient solution were slightly higher than $30 \%$ for most crops and similar for both oxygen treatments. High drain DO levels were given by cooled NST- $22{ }^{\circ} \mathrm{C}$ and NST- $25{ }^{\circ} \mathrm{C}$ in all cropping periods although cropping period (June-August) was more in drain DO levels in all treatments then in the other two cropping periods (Figures 4a, 4b, 8a, 8b, 12a and 12b). Our results are in agreement with Urrestarazu and Mazuela (2005) who reported that high drainage DO levels were found for tomato in summer and cucumber in fall with new growing channel. Davis et al. (2010) who found that oxygen concentrations decreased even further to virtually ambient levels when measured in the drain water or in the substrate reservoir.

\subsection{Dissolved Oxygen Consumption}

The temperature of the nutrient solution has a direct relation to the amount of oxygen consumed by plants, and an inverse relation to the oxygen dissolved. The consumption of $\mathrm{O}_{2}$ increases when the temperature of nutrient solution increases. Consequently, it produces an increase in the relative concentration of $\mathrm{CO}_{2}$ in the root environment if the root aeration is not adequate (Morard \& Silvestre, 1996). The present results showed high DO consumption was given by cooled RZT-22 ${ }^{\circ} \mathrm{C}$ and cooled RZT-25 ${ }^{\circ} \mathrm{C}$ and the lowest was given by control-uncooled RZT-33 ${ }^{\circ} \mathrm{C}$ in all cropping periods (Tables 1, 5 and 9) however, cropping period (June-August) showed more DO consumption than the other two cropping periods which meant that plant or roots exposure to cooled temperatures have more aeration which results in more respiration and metabolic processes. The present results obtained are in line with Masaru et al. (2016) who reported that root-zone heating at $30^{\circ} \mathrm{C}$ significantly 
reduced root oxygen consumption in comparison with that at $10{ }^{\circ} \mathrm{C}$ and $20{ }^{\circ} \mathrm{C}$ root zone temperature condition. Schroeder and Lieth (2004) reported that DO results in solution (input) and drain (output) showed for all substrates a positive balance for UC-mix substrates the highest oxygen consumption $\left(0.4762\right.$ and $0.529 \mathrm{mg} \mathrm{\textrm {O } _ { 2 }}$ plant/d). Gislerod and Kempton (1983) reported strong damage in cucumber plant at low oxygen concentration (below $3 \mathrm{mg} / \mathrm{L}$ ).

\subsection{Growth Parameters}

Oxygen availability to roots grown in soilless culture can become limiting in case oxygen demand exceeds oxygen supply, inducing reduced root growth rate, ion and water uptake, eventually reducing production (Pezeshki et al., 1993). Plants grown in hydroponic systems can quickly deplete the DO in the nutrient solution resulting in poor root aeration especially when greenhouse temperatures are high (Zinnen, 1988). Jong et al. (2014) indicated that some of the growth parameters of cucumber plant significantly affected by root-zone aeration; stem diameter, leaf area, petiole and leaf dry weight was quadratically changed with peak values under $0.5 \mathrm{~L} / \mathrm{min}$ of aeration. The present results in (Tables 2, 6 and 10) obtained showed significant effect of cooled nutrient solution and root-zone of cucumber roots in all cropping periods (June-August, September-November and February-May) which positively reflect to DO and growth parameters e.g. plant height, leaf number, leaf area and chlorophyll content which can explained by roots respiration and metabolic activity. Schroeder and Lieth (2002). Indicated that DO in the nutrient solution has direct influence on roots faction particularly respiration. Our findings are similar to that of Youbin et al. (2007) who showed that in the study of tomato (Lycopersicon lycopersicum Mill., cv. Trust) seedlings were grown in nutrient solutions containing DO concentration ranging from 5.3 to $40 \mathrm{mg} / \mathrm{L}$ for 4 weeks almost all the measured growth parameters (fresh and dry weights of root, stem, and leaf number, leaf area, stem diameter) were significantly reduced in plants grown in the $40 \mathrm{mg} / \mathrm{L}$ treatment compared to plants in the lower level of DO treatments, except that the plant height increased with the increasing DO concentration. Nichols et al. (2002) clarified that growing tomato and cucumber in an aeroponics plants relative growth rates were significantly lower with root-zone oxygen levels of $5 \%$ and $10 \%$ than with ambient DO (20\%). Holtman et al. (2005).Concluded that total leaf area of cucumber plants, which are grown under low oxygen conditions, is significant lower, than the leaf area of plants, which are grown under medium $(3.5 \mathrm{mg} / \mathrm{L})$, or oxygen rich $(6 \mathrm{mg} / \mathrm{L})$ conditions therefore, oxygen is of significant importance for plant development.

\subsection{Yield Parameters}

Several physiological processes inside the roots require energy, which is generated by oxygen dependent dissimilation. Hence, depletion of oxygen in the root system could result in reduced root activity and development leading to growth retardation, and eventually reduced yield (Holtman et al., 2005). The results of present study revealed the positive effect of cooled nutrient solution reflecting to DO levels and in turn in fruit number and yield of cucumber in all cropping periods ( June-August, September-November and February-May) in both the years $2016 / 2017$ and 2017/2018 (Tables 3, 7 and 11). Higher fruit number $/ \mathrm{m}^{2}$ and yields were produced by cooled RZT- $22{ }^{\circ} \mathrm{C}$ and cooled RZT- $25{ }^{\circ} \mathrm{C}$ with high levels of DO and the lowest yield given by control- RZT- $33{ }^{\circ} \mathrm{C}$ (Table 3) in all cropping periods. These are in a agreement with Bonachela et al. (2010) who reported absence of significant differences between oxygen treatments for any productivity parameter for the melon grown on perlite grow-bags whereas a significant $7 \%$ increase in total and marketable yield, associated with a higher fruit number, was observed for the oxygen enriched treatment grown on rockwool slabs. Jong et al. (2014) reported the highest cucumber fruit yield of $1.13 \mathrm{~kg} / \mathrm{plant}$ at aeration of $0.5 \mathrm{~L} / \mathrm{min}$, whereas at $2.0 \mathrm{~L} / \mathrm{min}$ it was $0.62 \mathrm{~kg} / \mathrm{plant}$. Similarly Gislerod and Kempton (1983) reported reduction of growth rates, root mass, root appearance, leaf area, water consumption and yield by low $\mathrm{O}_{2}$ levels in the nutrient solutions. In our study no any DO treatment was used, it was ambient DO in the nutrient solution, which was sufficient for the plant roots. For hydroponically-grown vegetable crops, the critical oxygen partial pressure of the nutrient solution was between 4-6\% (Schapira et al., 1990; Morard, 1995) that corresponded to DO concentration values of around 3 mg/L (Gislerod \& Kempton, 1983; Zeroni et al., 1983; Holtman et al., 2005).

\subsection{Quality Attributes}

Increased DO levels did not affect fruit length and fruit diameters of cucumber fruits in all cropping periods and the results were inconsistent between the cropping periods, whereas total soluble solids percentage as brix had significant effect with cooled RZTs in summer cropping period (June-August), while no any significant effect in the other two cropping periods, whereas not any effect with DO levels in all cropping periods in both the years 2016/2017 and 2017/2018 (Tables 4, 8 and 12). Schnitzler and Gruda (2003) concluded that better quality can be obtained by direct measures such as an increase in the concentration of the nutrient solution, or a reduction of 
nitrate application rates in vegetables, or via indirect measures to use threshold levels for growth factors as the quality of product is a complex characteristic that depends on several factors; such as temperatures, light, and irrigation. According to Schapira et al. (1990), the oxygen dissolved in the nutrient solution of a cucumber crop is depleted within approximately 30 minutes. This process, which is driven by root respiration and microbial activity, is affected by factors such as the temperature in the nutrient solution, root biomass, light and $\mathrm{CO}_{2}$ concentration. The first symptom of oxygen stress of the roots is leaf wilting for prevention of which nutrient replenishment, as well as aeration of the nutrient solution, is usually recommended.

\section{Conclusion}

Nutrient solution cooling provided positive effects on the availability of DO levels in nutrient solutions of feeding tanks and drain nutrient solution as well as on all growth parameters (plant height, leaf number, chlorophyll content, leaf area) and production parameters (Number of fruits and yield ) in all the three cropping periods studied. It can be concluded that cooled RZT of $22{ }^{\circ} \mathrm{C}$ and RZT of $25{ }^{\circ} \mathrm{C}$ were the best for cucumber production especially during high temperature periods. Therefore, this study suggested that availability of optimum aeration (oxygen levels) in nutrient solution by cooling of nutrient solution temperature is important for cucumber during the growing seasons especially in summer cropping periods in Oman.

\section{Acknowledgements}

The authors' expresses are grateful to the financial grants of Agriculture and Fisheries Development Fund (AFDF) of the Ministry of Agriculture \& Fisheries for the research project leading to Ph.D. degree of the main author who also thank the Director General of Agriculture \& Livestock Research, Director of Plant Production Research Center and Director of Soil and Water Research Center for their supports in logistics and facilities to conduct several experiments. Thanks are also to the advisor, members of the advisory committee and all the concerned staff of the College of Agriculture \& Marine Sciences and Directorate General of Agriculture \& Livestock Research (DGALR) who have directly and indirectly assisted in conducting the experiments of the research project.

\section{References}

Acuna, R., Gill, L., Bonachela, S., \& Magan, J. J. (2008). Oxyfertigation of greenhouse Melon crop grown in rockwool slabs in a Mediterranean area. Acta Hort (ISHS), 779, 447-454. https://doi.org/10.17660/ ActaHortic.2008.779.56

Adams, P. (2002). Nutritional control in hydroponics (pp. 211-261).

Che'rif, M., Tirilly, Y., \& Be'langer, R. R. (1997). Effect of oxygen concentration on plant growth, lipid peroxidation, and receptivity of tomato roots to pythium under hydroponic conditions. Eur. J. Plant Pathol., 103, 255-264. https://doi.org/10.1023/A:1008691226213

Chun, C., \& Takakura, T. (1994). Rate of root respiration of lettuce under various dissolved oxygen concentrations in hydroponics. Environ. Control Biol., 32, 125-135. https://doi.org/10.2525/ecb1963.32.125

Ehret, D. L., Edwards, D., Helmer, T., Lin, W. C., Jones, G., Dorais, M., \& Papadopoulos, A. P. (2010). Effects of oxygen-enriched nutrient solution on greenhouse cucumber and pepper production. Scientia Horticulturae, 125, 602-607. https://doi.org/10.1016/j.scienta.2010.05.009

Falah, M. A. F., Wajima, T., Yasutake, D., Sago, Y., \& Kitano, M. (2010). Responses of Root Uptake to High Temperature of Tomato Plants (Lycopersicon esculentum Mill.) in Soilless Culture. Journal of Agricultural Technology, 6, 543-558.

Glinski, J., \& Stepniewski, W. (1985). Soil Aeration and Its Role for Plants (p. 229). CRC Press Inc., Boca Raton, Florida, USA.

Graves, C. J. (1983). The Nutrient Film Technique. Horticultural Reviews, 5(1), 1-44. https://doi.org/10.1002/ 9781118060728.ch1

Janick, J. (1979). Horticultural Science (p. 147). W.H. Freeman \& Co, USA.

Jones, B. J. (2005). Hydroponics: A practical guide for soilless grower (2nd ed.).

Jong, W. L., Beom, S. L., Jong, G. K., Jong, H. B., Yang, G. K., Shela, G., \& Jeong, H. L. (2014). Effect of root zone aeration on the growth and bioactivity of cucumber plants cultured in perlite substrate. Biologia, 69(5), 610-617.

Lenzi, A., Baldi, A., \& Tesi, R. (2011). Growing spinach in a floating system with different volumes of aerated or non aerated nutrient solution. Adv. Hort. Sci., 25(1), 21-25. 
Libia, I., \& Fernando, C. (2012). Nutrient Solutions for Hydroponic Systems Colegio de Postgraduados, Montecillo, Texcoco, State of Mexico, Mexico.

Masaru, S., Mayuka, U., Kengo, M., \& Takahiro, S. (2016). Effect of root-zone temperature on the growth and fruit quality of hydroponically grown strawberry plants. Journal of Agricultural Science, 8(5), 122. https://doi.org/ $10.5539 /$ jas.v8n5p122

Mobini, S. H., Mohammed, R., \& Arouiee, I. H. (2015). The impact of aeration on potato minituber production under soilless conditions. African Journal of Biotechnology, 141(11), 910-921.

Morard, P. (1995). Étude de l'oxygénation du systeme racinaire. Les cultures végétales hors-sol (pp. 245-252). Pub Agricoles, Agen, France.

Morard, P., \& Silvestre, J. (1996). Plant injury due to oxygen deficiency in the root environment of soilless culture: A review. Plant Soil, 184, 243-254. https://doi.org/10.1007/BF00010453

Morard, P., Lacoste, L., \& Silvestre, J. (2000). Effect of oxygen deficiency on uptake of water and mineral nutrient by tomato plants in soilless culture, J. Plant Nutri., 23(8), 1063-1078. https://doi.org/10.1080/ 01904160009382082

Nichols, M. A., Wooltey, D. J., \& Christie, C. B. (2002). Effect of oxygen and carbon dioxide concentration in the root-zone on the growth of vegetables. Acta Hortic (ISHS), 570, 119-122. https://doi.org/10.17660/ ActaHortic.2002.578.13

Pezeshki, S. R., Pardue, J. H., \& Delaune, R. D. (1993). The influence of soil oxygen deficiency on alcohol dehydrogenase activity, root porosity, ethylene production and photosynthesis in Spartina patens. Env. And Exp. Bot., 33(4), 565-573. https://doi.org/10.1016/0098-8472(93)90031-A

Savvas, D., \& Passam, H. (2002). Hydroponic production of vegetable and ornamental. Embryo Publication (pp. 263-298). Athen, Greece.

Schapira, A., Morard, P., \& Maertens, C. (1990). Échanges gazeux racinaires du concombre et de la tomate en culture hydroponique. CR Acad Agric Fr, 76(4), 59-66.

Schroeder, F. G., \& Engwicht, K. (2005). Gas concentration in the root-zone of Rose hydrida L. grown in different growing media. Acta Hort (ISHS), 97, 49-55. https://doi.org/10.17660/ActaHortic.2005.697.4

Schroeder, F. G., \& Lieth, J. H. (2004). Gas composition and oxygen supply in root environment of substrates in closed hydroponic system. Acta Hort, 644(40). https://doi.org/10.17660/ActaHortic.2004.644.40

Soffer, H., Burger, D. W., \& Lieth, J. H. (1991). Plant growth and development of Chrysanthemum and Ficus in aeroponics: Response to low dissolved oxygen concentrations. Sci. Hort., 45, 287-297. https://doi.org/ 10.1016/0304-4238(91)90074-9

Urrestarazu, M., \& Mazuela, P. (2005). Effect of slow-release oxygen supply by fertigation on horticultural crops under soilless culture. Sci Hortic, 106, 484-490. https://doi.org/10.1016/j.scienta.2005.05.010

Villela, J., Luiz, V. E., Araujo, J. A. C. de, \& Factor, T. L. (2004). Nutrient Solution Cooling Evaluation for Hydroponic Cultivation of Strawberry Plant. Engenharia Agricola, 24(2), 338-346.

Zeroni, M. J., Gale, J., \& Ben, A. (1983). Root aeration in deep hydroponic system and its effect on growth and yield of tomato. Sci. Hort., 19, 213-220. https://doi.org/10.1016/0304-4238(83)90066-3

Zinnen, T. M. (1988). Assessment of plant diseases in hydroponic culture. Plant Dis, 72, 96-99. https://doi.org/ 10.1094/PD-72-0096

\section{Copyrights}

Copyright for this article is retained by the author(s), with first publication rights granted to the journal.

This is an open-access article distributed under the terms and conditions of the Creative Commons Attribution license (http://creativecommons.org/licenses/by/4.0/). 